\title{
Description of five new species of Acestrocephalus Eigenmann and redescription of $A$. sardina and $A$. boehlkei (Characiformes: Characidae)
}

\author{
Naércio A. Menezes
}

Acestrocephalus maculosus, A. stigmatus, A. nigrifasciatus, A. acutus, and A. pallidus are described as new species and A. sardina and $A$. boehlkei are redescribed. Acestrocephalus ginesi is considered synonymous with $A$. sardina. Specimens of Acestrocephalus anomalus, a valid trans-Andean species, were not available for study. Acestrocephalus stigmatus, A. maculosus, and $A$. boehlkei have a dark humeral blotch not present in the remaining species and the species within the two species groups thus characterized are told apart by meristic and morphometric data as well as morphological structures associated with the pseudotympanum.

Acestrocephalus maculosus, A. stigmatus, A. nigrifasciatus, $A$. acutus e $A$. pallidus são descritas como espécies novas, e $A$. sardina e $A$. boehlkei são redescritas. Acestrocephalus ginesi é considerada sinônimo de $A$. sardina. Não foram conseguidos para estudo exemplares de Acestrocephalus anomalus, espécie transandina válida. Acestrocephalus stigmatus, A. maculosus e $A$. boehlkei possuem uma mancha umeral escura que não está presente nas demais espécies e as espécies nos dois grupos de espécies caracterizados desta forma, são separadas através de dados merísticos e morfométricos, bem como estruturas morfológicas associadas com o pseudotímpano.

Key words: Freshwater fish, South America, Brazil, Taxonomy, Systematics.

\section{Introduction}

The genus Acestrocephalus Eigenmann was included with Galeocharax Fowler and Cynopotamus Valenciennes in the subfamily Cynopotaminae by Menezes (1976). Although not using a truly cladistic approach Menezes, based on a morphological character survey, considered the group monophyletic. In a subsequent contribution Lucena \& Menezes (2003) did not recognize Cynopotaminae and the three genera formerly representing the subfamily were included in the characid subfamily Characinae. The phylogenetic relationships of all the characin genera have yet to be studied and as reported by Lucena \& Menezes (2003) monophyly of the group is uncertain. Preliminary examination of the genera within the Characinae indicates that certain characters used by Menezes (1976) to define Cynopotaminae, including presence of ctenoid (actually spinoid) scales, shape, number and arrangement of premaxillary and dentary teeth and structure of the gill-rakers might be exclusive to Acestrocephalus, Galeocharax and Cynopotamus, suggesting that these genera are much more closely related among themselves than to any other genus in the Characinae.

Acestrocephalus is presently represented by four species: A. anomalus (Steindachner), A. sardina (Fowler), A. boehlkei Menezes, and $A$. ginesi Lasso \& Taphorn. Five new species were discovered in material recently collected in expeditions carried out in different regions of Brazil. Additional specimens of $A$. sardina and $A$. boehlkei were also obtained. The type specimen of $A$. sardina, a juvenile (31.4 $\mathrm{mm} \mathrm{SL}$ ) not previously seen by me was examined and photographed by my colleague Heraldo Britski.

Recognition of new species and new data from $A$. sardina and $A$. boehlkei allowed for a better characterization of the species in the genus, with exception of $A$. anomalus as new material and previously examined specimens were unavailable.

Herein, the five new species of Acestrocephalus are described and $A$. sardina and $A$. boehlkei are redescribed. 


\section{Materials and Methods}

This research is based on specimens examined from the following institutions: Museu de Zoologia, Universidade de São Paulo, São Paulo (MZUSP); Museu Nacional, Rio de Janeiro (MNRJ); Museu de Ciências e Tecnologia, Pontifícia Universidade Católica do Rio Grande do Sul, Porto Alegre (MCP).

Counts, measurements, and presentation of data follow Fink \& Weitzman (1974) and Menezes (1976, 1977), unless otherwise stated. The number of scales above and below lateral line and around caudal peduncle correspond to the number of horizontal scale rows. The number of gill-rakers includes only developed elements, not rudiments in both the upper and lower gill-arches. Examination of mature males under the stereomicroscope did not reveal the presence of gill glands on the first gill-arch. Measurements were taken whenever possible on the left side of the specimens, using dial calipers, recorded to a tenth of a millimeter and expressed as percentages of standard length (SL), except for subunits of the head, expressed as percentages of head length (HL). Data from Acestrocephalus anomalus and $A$. boehlkei in part were extracted from Menezes $(1976,1977)$. All measurements were taken point to point.

Meristic and morphometric data of males and females were treated separately to assess possible differences between sexes, but none were found. Immature as well as males and females were recognized by examination of gonads under the stereomicroscope. Vertebral counts were taken from radiographs and include the four vertebrae of the Weberian apparatus and the terminal "half centrum".

To show the arrangement of the muscles around the pseudotympanum the skin and adipose tissue covering the muscular hiatus were carefully removed and all muscles exposed (Fig. 1). In the schematic drawings prepared for each

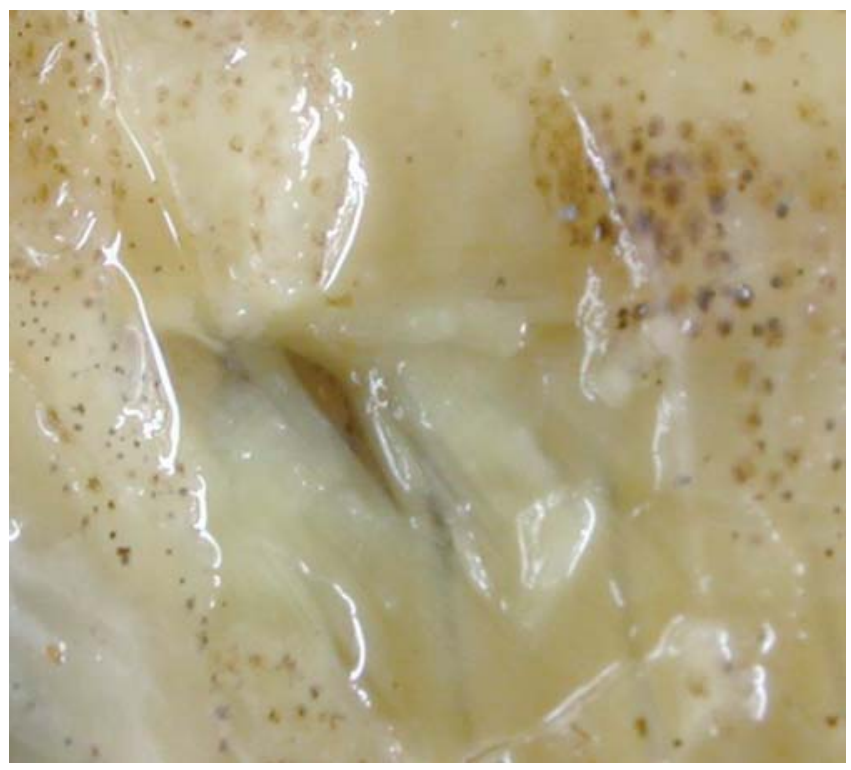

Fig. 1. Acestrocephalus maculosus, MNRJ 12657, paratype, $44 \mathrm{~mm}$ SL. External view of muscles covering the anterior portion of the swim bladder. Anterior towards left; skin and adipose tissue removed. species muscles and other structures are represented as they appear after removal of skin and adipose tissue. The structure of the pseudotympanum does not seem to vary ontogenetically as no major differences were found in specimens of different sizes in all species examined.

In the descriptions, counts pertaining to the holotype are presented first, followed in parentheses by the mean of the sample, range, and the total number of specimens counted. The statistical procedure was standardized for comparative purposes even though samples of some species are represented by very few specimens.

\section{Results}

\section{Acestrocephalus Eigenmann, 1909}

Acestrocephalus Eigenmann, 1910:447. Type species: Xiphorhamphus anomalus Steindachner, 1880. Type by original designation. Gender: masculine.

Diagnosis. Acestrocephalus can be distinguished from the remaining genera of the Characinae sensu Lucena \& Menezes (2003) by the following unique combination of morphological characters extracted from Menezes (1976: 37) with the addition of new ranges of meristic and morphometric characters for the genus due to the values of the new species described herein.

Body comparatively small (SL 31.4-135 mm); anterior dorsal region not elevated; dorsal body profile regularly curved from tip of snout to caudal base; lower part of antorbital only in contact with maxilla; first infraorbital relatively short, high on its median part; nasal bone tubular; cleithrum not notched, just with a slight sinuosity along its ventral edge; ectopterygoid with a median ventral bony crest; supraoccipital spine short; dentary with two rows of teeth, anterior teeth of external row much larger than posterior ones; first and third anterior teeth canine-like, more developed than the other two; posterior dentary tooth row with 20-40 small conical teeth slightly curved posteriorly, their number tending to increase with an increase in standard length; inner row of teeth on dentary formed by 7-14 small conical teeth; scales comparatively large and numerous, perforated lateral-line scales 67-79, 10-15 above and 9-13 below lateral line; anal fin comparatively short, with iv-v,25-36 rays, its origin situated on vertical line always crossing behind middle of dorsal-fin base length; pectoral fin with i,11-16 rays.

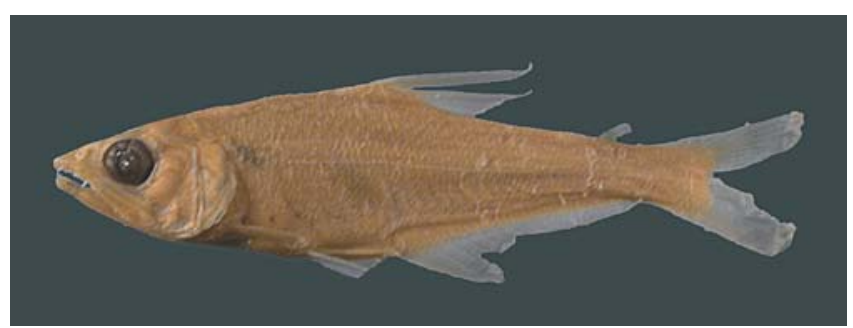

Fig. 2. Acestrocephalus sardina, ANSP 39307, holotype, 31.4 $\mathrm{mm}$ SL; rio Madeira, Brazil. 


\section{Key to species of Acestrocephalus}

1. A black spot at humeral region slightly posterior and dorsal to pseudotympanum, very small and sometimes indistinct in very young specimens .......................................................

$1^{\prime}$ '.No black spot at humeral region ............................................. 4

2. Horizontal scale rows around caudal peduncle 24-25; 10-12 small conical teeth between first and last larger conical teeth in the external premaxillary tooth row; 75-78 lateral line scales A. boehlkei

2 '. Horizontal scale rows around caudal peduncle 22-23; 7-9 small conical teeth between first and last larger conical teeth in the external premaxillary tooth row; 70-74 lateral line scales .... 3

3. Branched anal-fin rays $25-27$; 7-8 developed gill-rakers on first branchial arch; 22-29 small conical teeth in posterior dentary tooth row ..... A. maculosus

3 '.Branched anal-fin rays 29-31; 5-6 developed gill-rakers on first branchial arch; 33-37 small conical teeth in posterior dentary tooth row ..... A. stigmatus

4. A triangular dark blotch on caudal base anteriorly continuous with dark longitudinal stripe approximately on midbody in freshly preserved specimens; $40-46$ maxillary teeth ......... 5

4'.Dark blotch on caudal base absent or oblong, oval-shaped, anteriorly continuous with dark longitudinal stripe; 24-38 maxillary teeth

5. Horizontal scale rows around caudal peduncle $20-22 ; 10-12$ horizontal scale rows above lateral line, $10-12$ below lateral line A. sardina

5'.Horizontal scale rows around caudal peduncle 23-24; 13-14 horizontal scale rows above lateral line, $12-13$ below lateral line A. nigrifasciatus

6. Caudal-fin base with few scattered dark chromatophores never forming a conspicuous dark blotch ....... A. pallidus

6'. Caudal-fin base with oblong dark blotch, conspicuous and continuous with longitudinal dark stripe on body .......... 7

7. Posterior dentary tooth row with 23-28 teeth; 8-11 small conical teeth in external tooth row on premaxilla; 9-11 inner dentary teeth A. anomalus

$7^{\prime}$.Posterior dentary tooth row with $28-36$ teeth; 6-8 small conical teeth in external tooth row on premaxilla; $10-13$ inner dentary teeth. A. acutus

\section{Acestrocephalus sardina (Fowler, 1913)} Figs. 2-3

Charax sardina Fowler, 1913: 566, fig. 2 (type locality: Madeira River, about 200 miles east of W. long. $60^{\circ} 20^{\prime} \mathrm{W}$, Brazil); Böhlke, 1984: 32 (catalog); Eschmeyer, 1998: 1507 (catalog). Cyrtocharax sardina; Fowler, 1950: 312 (listed).

Cynopotamus (Acestrocephalus) sardina; Géry, 1972: 28 (diagnosis in key).

Acestrocephalus sardina; Menezes, 1976: 39 (in part, only specimens from rio Aripuanã, MZUSP 10423); Eschmeyer, 1998: 1507 (catalog); Lucena \& Menezes, 2003: 200 (in check list; maximum length, distribution).
Acestrocephalus ginesi Lasso \& Taphorn, 2000: 443 (type locality: Venezuela, Apure State, Río Cinaruco, playa en frente de Laguna Larga, Distrito Muñoz (06 $33^{\circ} 45^{\prime \prime} \mathrm{N}$ $67^{\circ} 24^{\prime} \mathrm{W}$ ); holotype not seen; topotypes examined); Lucena \& Menezes, 2003: 200 (in check list; maximum length; distribution); Lasso, Lew, Taphorn, Nascimiento, Lasso-Alcalá \& Machado-Allison, 2004: 148 (listed).

Acestrocephalus cf. ginesi; Lima et al., 2005: 166 (description; habitat; feeding habits; fisheries).

Material examined. ANSP 39307, holotype, $31.4 \mathrm{~mm}$ SL, (data taken by H.A. Britski; digital image and radiographs examined), Brazil, Mato Grosso: rio Madeira system, by Edgar A. Smith, 1912; MZUSP 10423, 1, 89 mm SL, Aripuanã: rio Aripuanã, 9³4'S 59²5'W; MZUSP 60396, 1, 94 mm SL, rio Aripuanã, Porto de Balsa on the road between Colmiza and Panela, $10^{\circ} 09^{\prime} \mathrm{S} 67^{\circ} 27^{\prime} \mathrm{W}$. MZUSP 29237, 11, 49-65 mm SL, Amazonas: ilha de Tamaquaré, rio Negro; MZUSP 29239 and 29241, 36, 50-71 mm SL, Marauiá: rio Negro; MZUSP 29240, 5, 51-66 mm SL, Massarabi: rio Negro; MZUSP 31140, 1, 84 mm SL, Cachoeira de São Gabriel: rio Negro; MZUSP 29238 and 31036, 6, 47.5-86 mm SL, Paraná do Jacaré: rio Negro. MZUSP 81209 and 81259, 4, 81-94 mm SL, rio Tiquié, indian village of Cururu, $0^{\circ} 16^{\prime} \mathrm{N} 69^{\circ} 54^{\prime} \mathrm{W}$. MZUSP 56558, 2, 62 and $65 \mathrm{~mm}$ SL, rio Jutaí, 2 ${ }^{\circ} 57^{\prime} \mathrm{S} 67^{\circ} 0^{\prime} \mathrm{W}$; MZUSP 35498, 3, 52-69 mm SL,Venezuela, Apure: Río Orinoco system, $1^{\circ} 55^{\prime} \mathrm{N} 67^{\circ} 04^{\prime} \mathrm{W}$. MZUSP 35499, 5, 53.7-82.6 mm SL, Rio Negro: Río Negro, near San Carlos do Rio Negro.

Diagnosis. Acestrocephalus sardina is most similar to $A$. nigrifasciatus, both having identical color patterns consisting of a triangular dark blotch on caudal-fin base, anteriorly continuous with a longitudinal dark stripe extending along lateral line (Figs. 3 and 12) not found in any other species of the genus. In addition, both have the eye diameter greater than their congeners (Fig. 4). Acestrocephalus sardina can be distinguished from $A$. nigrifasciatus by having fewer horizontal scale rows above lateral line (10-12 vs 13-14) and below (10-12 vs 12-13). See Tables 1 and 2. Acestrocephalus nigrifasciatus also has the muscular hiatus over the anterior part of the swim bladder which is longer than and narrower than A. sardina and the fibers of the obliquus inferioris muscle, visible in the latter are entirely covered by the obliquus superioris muscle in the former (compare Figs. 5a and 5e).

Description. Morphometrics of holotype and additional specimens presented in Table 3. Meristic and morphometric data based on all lots for this species because no statistical

Table 1. Frequency distribution of scales above lateral line in the species of Acestrocephalus.

\begin{tabular}{|c|c|c|c|c|c|c|}
\hline Scales above lateral line & 10 & 11 & 12 & 13 & 14 & 15 \\
\hline A. sardina & 1 & 51 & 24 & & & \\
\hline A. boehlkei & & & & 12 & 6 & 3 \\
\hline A. pallidus & & & 48 & 12 & & \\
\hline A. nigrifasciatus & & & & 7 & 5 & \\
\hline A. acutus & & & 5 & 40 & 1 & \\
\hline A. stigmatus & & & & 4 & 2 & \\
\hline A. maculosus & & & & & 6 & \\
\hline
\end{tabular}




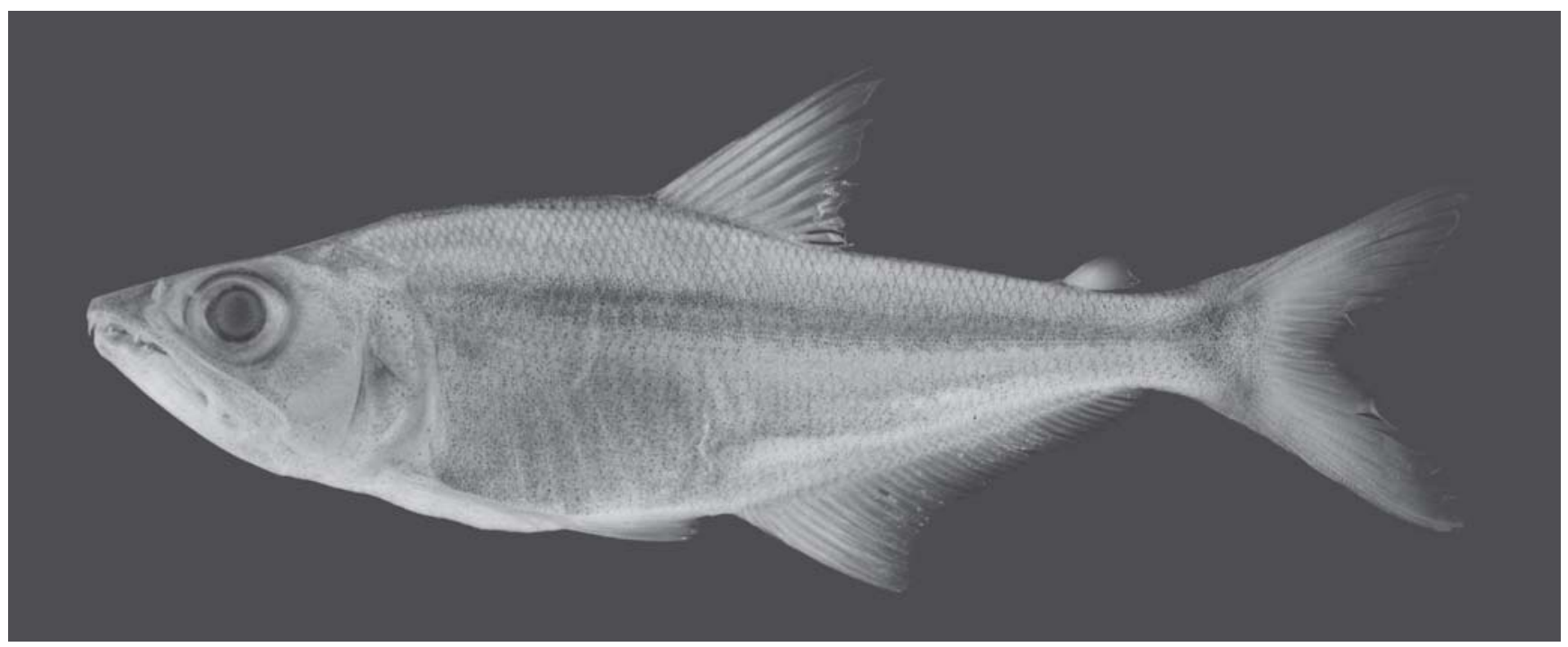

Fig. 3. Acestrocephalus sardina, MZUSP 81209, $93 \mathrm{~mm}$ SL, immature female, rio Tiquié, rio Negro drainage.

Table 2. Frequency distribution of scales below lateral line in the species of Acestrocephalus.

\begin{tabular}{lcccc}
\hline \multicolumn{1}{c}{ Scales below lateral line } & 10 & 11 & 12 & 13 \\
\hline A. sardina & 58 & 16 & 2 & \\
A. boehlkei & & & 18 & 3 \\
A. pallidus & 5 & 55 & & \\
A. nigrifasciatus & & & 5 & 7 \\
A. acutus & 1 & 22 & 23 & \\
A. stigmatus & & 3 & 3 & \\
A. maculosus & & & 6 & \\
\hline
\end{tabular}

Table 3. Morphometrics of Acestrocephalus sardina. Standard length is expressed in $\mathrm{mm}$; measurements through head length are percentages of standard length; last four entries are percentages of head length. Specimens are from ANSP 39307 (holotype), MZUSP 29237-241, 31140, 31036, 81209, $35498,35499,60396,10423,56558$.

\begin{tabular}{lccccc}
\hline \multicolumn{1}{c}{ Characters } & Holotype & $\mathrm{N}$ & Range & Mean & SD \\
\hline Standard length & 31.4 & 76 & $31.4-90.0$ & & \\
Body depth & 26.1 & 66 & $24.9-30.8$ & 28.0 & 1.2 \\
Snout to dorsal-fin origin & 49.0 & 76 & $48.2-50.3$ & 50.1 & 0.9 \\
Snout to pectoral-fin origin & 31.2 & 76 & $28.6-33.4$ & 30.4 & 1.2 \\
Snout to pelvic-fin origin & 42.0 & 76 & $40.4-45.6$ & 43.0 & 1.2 \\
Snout to anal-fin origin & 57.3 & 76 & $56.1-62.7$ & 58.9 & 1.5 \\
Caudal peduncle depth & 8.6 & 76 & $6.1-8.6$ & 7.9 & 0.3 \\
Caudal peduncle length & 10.8 & 76 & $9.2-12.6$ & 10.7 & 0.8 \\
Pectoral-fin length & 17.5 & 76 & $16.2-19.4$ & 17.6 & 0.6 \\
Pelvic-fin length & 16.8 & 76 & $13.1-17.8$ & 15.5 & 0.9 \\
Dorsal-fin base length & 11.1 & 76 & $11.0-14.3$ & 12.7 & 0.6 \\
Dorsal-fin height & 27.4 & 76 & $22.7-28.0$ & 25.1 & 1.1 \\
Anal-fin base length & 37.2 & 76 & $31.4-37.3$ & 34.0 & 1.0 \\
Anal-fin lobe length & 20.0 & 76 & $16.3-21.8$ & 18.3 & 1.1 \\
Eye to dorsal-fin origin & 35.0 & 76 & $31.7-36.0$ & 33.2 & 0.8 \\
Dorsal-fin origin to & 52.2 & 76 & $49.5-54.3$ & 51.8 & 0.9 \\
caudal-fin base & 30.2 & 76 & $30.1-33.3$ & 31.8 & 0.7 \\
Head length & 31.5 & 76 & $31.3-37.4$ & 34.4 & 1.2 \\
Horizontal eye diameter & 28.4 & 76 & $26.0-31.5$ & 28.0 & 0.9 \\
Snout length & 21.0 & 76 & $16.6-21.4$ & 19.3 & 1.0 \\
Least interorbital width & 67.3 & 76 & $62.4-69.1$ & 65.2 & 1.4 \\
Upper jaw length & & & & &
\end{tabular}

differences found among population samples studied, in spite of wide distribution of species. Body elongate, relatively large $(\mathrm{SL}=31.4-90 \mathrm{~mm})$, compressed and not very deep; greatest body depth between occiput and dorsal-fin origin near middle of pelvic-fin length. Dorsal body profile nearly straight, but inclined ventrally from snout tip to base of supraoccipital spine, slightly convex between that point and dorsal-fin origin, nearly straight along dorsal-fin base, and straight or nearly so from base of dorsal-fin termination to caudal peduncle. Ventral body profile convex from tip of lower jaw to anal-fin

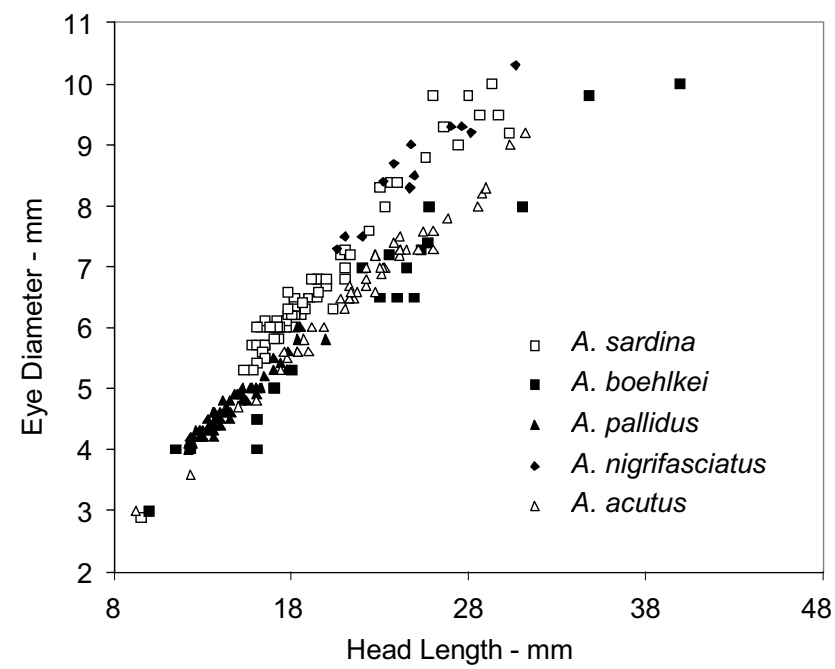

Fig. 4. Scatter plot of eye diameter on head length for specimens of Acestrocephalus sardina, A. boehlkei, A. pallidus, A. nigrifasciatus and A. acutus. Acestrocephalus sardina and A. nigrifiasciatus have larger eye diameters than the other species suggesting the recognition of two species groups with respect to this character (see diagnoses of $A$. sardina and $A$. nigrifasciatus). 


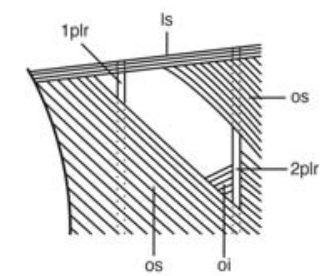

a

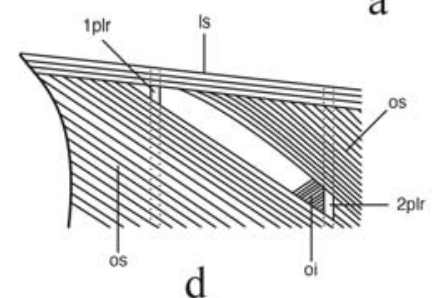

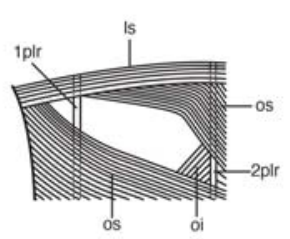

b
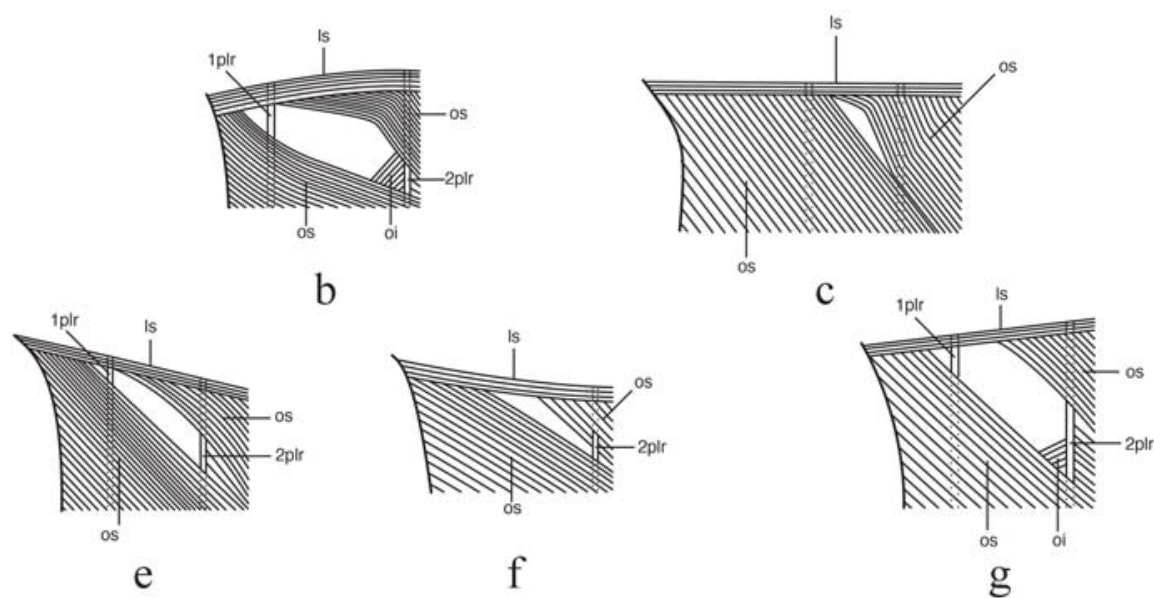

Fig. 5. Schematic drawings of external view of muscles covering the anterior portion of the swim bladder in $\mathrm{A}-$ Acestrocephalus sardina (MZUSP 29241); B - A. boehlkei (MZUSP 38699); C - A. maculosus (MNRJ 12657); D - A. stigmatus (MZUSP 10422); $\mathrm{E}-$ A. nigrifasciatus (MCP 30420); F - A. acutus (MNRJ 17612); G - A. pallidus (MZUSP 73471). Anterior towards left; 1 plr (first pleural rib); 2 plr (second pleural rib); os (obliquus superioris); 1s (lateralis superficialis); oi (obliquus inferioris). Not drawn to scale.

origin, nearly straight and dorsally inclined along anal-fin base and slightly concave from base of posterior most analfin ray to origin of procurrent caudal-fin rays. Snout pointed. Lower jaw included in upper jaw when mouth is fully closed. Mouth angled posteroventrally from anterior tip of snout to posterior part of mandibular joint. Maxilla extending slightly beyond vertical line passing through posterior border of orbit.

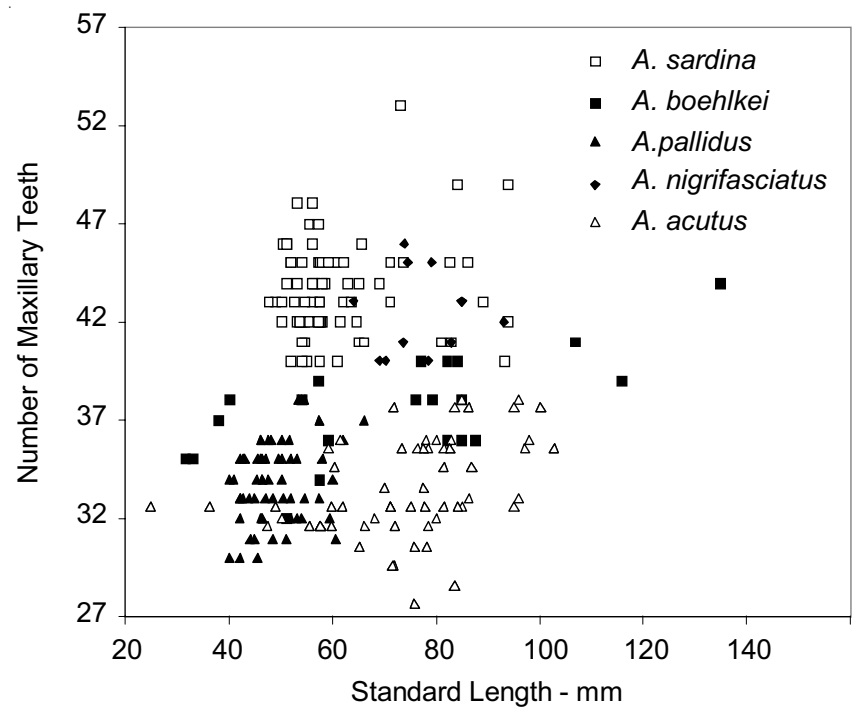

Fig. 6. Scatter plot of number of maxillary teeth on standard length for specimens of Acestrocephalus sardina, A. boehlkei. Acestrocephalus nigrifasciatus, A. pallidus, and $A$. acutus. The figure is not intended to show species differences therefore regression lines were not drawn and regression analyses were not performed. The primary purpose is to express the tendencies of the number of teeth on the maxilla to increase according to an increase in standard length. For the species represented by large number of specimens the data points are widely scattered.
Dorsal-fin rays ii, 9 in all specimens, $\mathrm{n}=76$, including holotype. Posterior most ray unbranched, $n=76$. Adipose fin present. Anal-fin rays iv,32 (iv or v, usually iv unbranched, branched rays mean $=30.3$, range $28-33, n=76$, posterior ray split to its base and counted as 1). Moderately developed anterior anal-fin lobe including anterior unbranched rays and first 7-8 branched rays. No hooks on anterior rays of males,

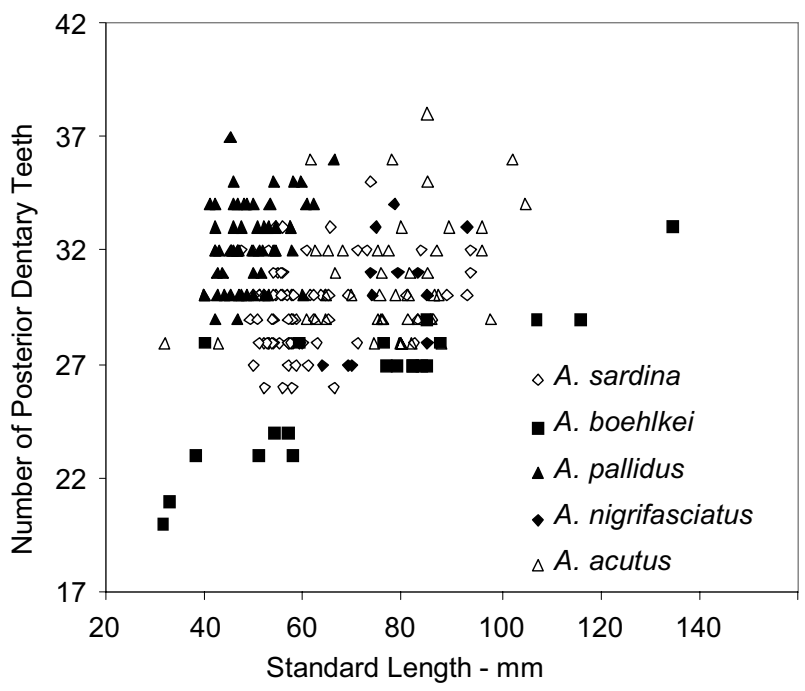

Fig. 7. Scatter plot of number of posterior dentary teeth for specimens of Acestrocephalus sardina, A. boehlkei, A. pallidus, A. nigrifasciatus, and $A$. acutus. The figure is not intended to show species differences therefore regression lines are not drawn and regression analyses were not performed. The primary purpose is to express the tendencies of the number of teeth on the posterior row on the dentary to increase according to an increase in standard length. For the species represented by large number of specimens the data points are widely scattered. 
but very few sexually mature males represented in examined sample. Pectoral-fin rays i, 13 (anterior unbranched ray i, $n=76$ ) branched rays mean $=13.6$, range $12-15, n=76$. Posterior tips of longest pectoral-fin rays reaching slightly beyond pelvic-fin origin. Pelvic-fin rays i, 7, $n=76$. No hooks on pelvic-fin rays of sexually mature males. Distal tips of longest pelvic-fin rays extending to or slightly beyond anterior border of anus. Principal caudal-fin ray count 10/9 in all specimens, $\mathrm{n}=76$.

Lateral line complete, perforated scales 73 (mean $=71.3$, range $67-74, n=76)$. Scale rows above lateral line 12 (mean=11.3, range $10-12, n=76)$. Scale rows below lateral line 10 (mean $=10.3$, range $10-12, n=76$ ). Scale rows around caudal peduncle 20 (mean=20.7, range 20-22, $\mathrm{n}=76$ ).

Premaxilla with two slightly enlarged inner conical teeth, an outer row with one anterior canine followed by row of small conical teeth and one posterior canine. Anterior canine outside anterior border of lower jaw when mouth closed. Outer row small conical teeth 8 (mean $=7.7$, range $7-9, n=75)$. Maxillary teeth 44 (mean $=43.6$, range $40-53, n=75)$. Maxillary teeth conical with tendency to increase in number according to increase in standard length (Fig. 6). Dentary with outer row of conical teeth of which four anterior most spaced and first and third larger than third and fourth, these followed by posterior row of close-set smaller conical teeth that show tendency to increase in number with increase in standard length (Fig. 7). Posterior dentary teeth 28 (mean $=29.4$, range 26-33, $n=75$ ). Teeth in inner row on dentary conical, very small, slightly inclined proximally to four anterior spaced larger conical teeth of outer row. Inner row dentary teeth 9 (mean=9.8, range 7-12, $\mathrm{n}=75$ ).

Vertebrae 38 (mean=39, range $38-40, n=35)$. Total number of gill-rakers on first gill-arch 7 (mean=7, range 6-8, $\mathrm{n}=76$ ).

Muscular hiatus of pseudotympanum (Fig. 5a) relatively large, dorsally limited by lateralis superficialis muscle, posteriorly by large exposed portion of second pleural rib, anteriorly by small exposed portion of first pleural rib, anteroventrally by large portion of the obliquus superioris and posteroventrally by small portion of obliquus inferioris muscle. Small opening anterior to first pleural rib visible.

Color in alcohol. Body pale to dark yellow, slightly darker dorsally than ventrally due to presence of dark chromatophores. Dark chromatophores on dorsal and lateral parts of trunk mostly concentrated along free border of scales. Dorsal part of head from tip of snout to supraoccipital region darker than remaining dorsal surface of body. Premaxilla, median part of maxilla and lower jaw densely pigmented with dark chromatophores. Scattered dark chromatophores on infraorbital and opercular bones. Lateral dark body stripe extending from upper opercle to caudal peduncle where fused with triangular dark blotch on caudal base, dark color extending to base of principal caudal rays. Lateral body stripe narrower anteriorly and posteriorly and sometimes obscured by guanine. Anterior part of lower jaw bordered with dark pigmentation. Mental area of lower jaw with diffuse dark blotch in some specimens. Dorsal-fin origin with black dot extending to base of

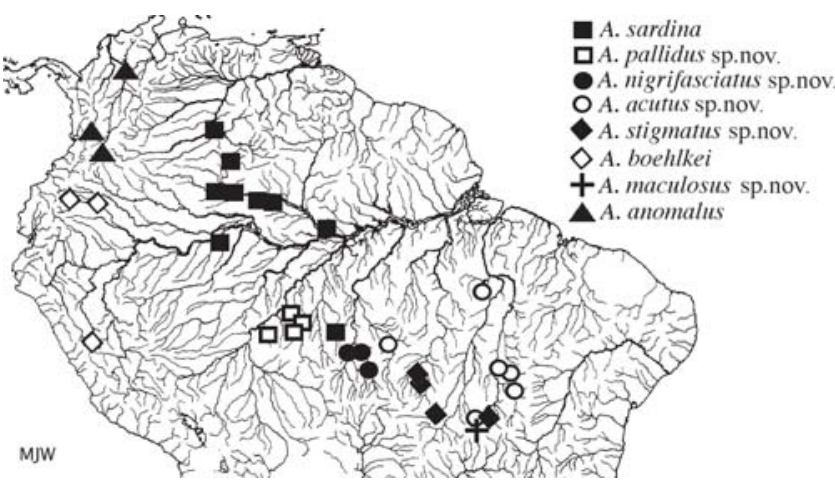

Fig. 8. Map of northern and central South America showing the geographic distribution of the species of Acestrocephalus. Some symbols may represent more than one locality.

first unbranched dorsal-fin ray. Pectoral, pelvic, dorsal, and caudal fins pale, with few scattered dark chromatophores.

Distribution. This species is known from tributaries of the rio Madeira, Mato Grosso, rio Jutaí and rio Negro, Amazonas, Brazil and of the Orinoco Basin, Venezuela (Fig. 8).

Remarks. Menezes' redescription of $A$. sardina (1976) was based on the examination of two specimens, one of them from rio das Mortes near Xavantina, Mato Grosso. It was mentioned that no differences had been found among them and a small dark blotch at the humeral region was described for the species. Actually, this spot is present only in the specimen from rio das Mortes considered to belong to A. stigmatus herein described. A dark humeral spot is never present in specimens of $A$. sardina. At that time it was predicted that the taxonomic status of $A$. sardina would be cleared up only after a study based on a large series of specimens.

Acestrocephalus ginesi Lasso \& Taphorn is herein considered a junior synonym of $A$. sardina. Five paraypes from Río Negro, near San Carlos de Río Negro, Venezuela (MZUSP 53499) and three specimens collected in the Apure State, near the type locality were studied and proved to be morphologically indistinguishable from specimens of the population samples representing $A$. sardina.

\section{Acestrocephalus boehlkei Menezes, 1977}

Fig. 9

Acestrocephalus boehlkei Menezes, 1977: 186, fig. 1 (original description, type locality: Río Punino, tributary of Río Payamino (Napo River system), above Coca, Ecuador).

Material examined. MCZ 51473, holotype, $135 \mathrm{~mm}$ SL (radiograph examined), Ecuador: Río Punino, tributary of Río Payamino, Río Napo system, by T. Roberts and Parker, 25-27 November 1971; MZUSP 12993-94, 2, paratypes 85-116 mm SL, taken with holotype; MZUSP 12995, 1 paratype, $40 \mathrm{~mm} \mathrm{SL}$, Río Payamino and tributary 3-4 miles upriver from mouth of Río Payamino into Coca, by T. Roberts, Garcia, Parker and Herrera, 20 November 
1971; MZUSP 38699, 2, 76-87.5 mm SL, Napo: Río Aguarico in Quarumo, Río Napo system, 0¹'S, 76³7.5'W. MZUSP 1299698, 3, paratypes, 59-85 mm SL, Peru, Huanuco: backwater near Pueblo Novo flowing into Río Tulumayo, by Catherwood Expedition, 27 September 1955.

Diagnosis. Acestrocephalus boehlkei, A. maculosus sp.n. and $A$ stigmatus sp.n. are the only species of the genus bearing a dark spot at the humeral region (Figs. 9, 10, and 11). Acestrocephalus boehlkei, however, has more anal-fin rays (34-36) than A. maculosus (25-27) and A. stigmatus (29-31) and more scale rows around caudal peduncle (25) than $A$. maculosus (23) and A. stigmatus (22-23). See tables 4 and 5. Additionally, $A$. boehlkei differs at once from $A$. maculosus and $A$. stigmatus in number of perforated lateral line scales (74-78 vs 70-73 in A. stigmatus and 71-73 in A. maculosus) and in number of small conical teeth between anterior and posterior canines of outer row premaxillary teeth(10-12 vs 7-9 in both A. stigmatus and A. maculosus (see Tables 6 and 7). The muscular hiatus of the pseudotympanum in A. boehlkei (Fig. $5 \mathrm{~b}$ ) is also wider than those of $A$. maculosus (Fig. 5c) and $A$. stigmatus (Fig. 5d).

Description. Morphometrics of holotype and additional specimens presented in table 8. Meristic and morphometric data based on all examined lots of this species because no statistical differences found among them. Body moderately large $(\mathrm{SL}=31.5-135.0 \mathrm{~mm})$. Body form, dorsal and ventral body profiles, shape of snout and mouth and extension of maxilla as in A. sardina.

Dorsal-fin rays ii, 9 in all specimens, $n=21$, including holotype. Posterior most ray unbranched, $n=21$. Adipose fin present. Anal-fin rays v,34 (iv or v, usually v unbranched, branched rays mean $=34.5$, range $33-36, n=21$, posterior ray split to its base and counted as 1). Slightly developed anterior anal-fin lobe including anterior unbranched rays and first 9-10 branched rays. Anal fin of three sexually mature males with bilateral hooks on posterior part of anterior branched rays. In a specimen $87.5 \mathrm{~mm}$ SL (MZUSP 38699) hooks present on anterior 11 branched rays and number of hooks per ray vary considerably: first branched ray with 9 , third with 17 , sixth with 24 and eleventh with 8 . Pectoral-fin rays i, 14 (anterior branched ray $i$ in all specimens, $n=21$ ), branched rays mean 14.6, range13-16, $n=21$. Posterior tips of longest pectoral-fin rays reaching beyond pelvic-fin origin. Pelvic-fin rays $i, 7, n=21$. No hooks on pelvic-fin rays of sexually mature males. Distal tips of longest pelvic-fin rays extending to or slightly beyond posterior border of anus, but not reaching anal-fin origin. Principal caudal-fin ray count $10 / 9, n=21$.

Lateral line complete, perforated scales 74 (mean=76.1, range $74-79, \mathrm{n}=21$ ). Scale rows above lateral line 13 (mean=13.5, range $13-15, \mathrm{n}=21$ ). Scale rows below lateral line 12 (mean=12.1, range $12-13, n=21$ ). Scale rows around caudal peduncle 25 in all specimens, $\mathrm{n}=9$.

Shape, size and arrangement of teeth on premaxilla, maxilla and dentary as in A. sardina. Outer row small conical
Table 4. Frequency distribution of branched anal-fin rays in the species of Acestrocephalus.

\begin{tabular}{|c|c|c|c|c|c|c|c|c|c|c|c|c|}
\hline Branched anal-fin rays & 25 & 26 & 27 & 28 & 29 & 30 & 31 & 32 & 33 & 34 & 35 & 36 \\
\hline A. sardina & & & & 2 & 13 & 32 & 19 & 8 & 2 & & & \\
\hline A. boehlkei & & & & & & & & 2 & 1 & 11 & 5 & 2 \\
\hline A. pallidus & & & & & & & & 11 & 14 & 26 & 8 & 1 \\
\hline A. nigrifasciatus & & & 1 & 4 & 4 & 1 & 1 & & & & & \\
\hline A. acutus & & & & & 1 & 2 & 7 & 20 & 5 & 6 & 1 & \\
\hline A. stigmatus & & & & & 2 & 2 & 2 & & & & & \\
\hline A. maculosus & 1 & 1 & 4 & & & & & & & & & \\
\hline
\end{tabular}

Table 5. Frequency distribution of scales around caudal peduncle in the species of Acestrocephalus.

\begin{tabular}{lcccccc}
\hline Scales around caudal peduncle & 20 & 21 & 22 & 23 & 24 & 25 \\
\hline A. sardina & 25 & 47 & 3 & & & \\
A. boehlkei & & & & & & 9 \\
A. pallidus & 31 & 25 & 4 & & \\
A. nigrifasciatus & & & & 10 & 2 & \\
A. acutus & & & 15 & 25 & 6 & \\
A. stigmatus & & & 3 & 3 & & \\
A. maculosus & & & & 6 & & \\
\hline
\end{tabular}

Table 6. Frequency distribution of lateral line scales in the species of Acestrocephalus.

\begin{tabular}{lcccccccccccc}
\hline Lateral line scales & 67 & 68 & 69 & 70 & 71 & 72 & 73 & 74 & 75 & 76 & 77 & 78 \\
\hline A. sardina & 1 & 4 & 4 & 14 & 14 & 19 & 17 & 2 & & & & \\
A. boehlkei & & & & & & & & 3 & 5 & 5 & 3 & 5 \\
A. pallidus & & 1 & 1 & 12 & 14 & 15 & 14 & 3 & & & & \\
A. nigrifasciatus & & & & 2 & 1 & 2 & 4 & 1 & 2 & & & \\
A. acutus & & & & 3 & 3 & 2 & 6 & 15 & 14 & 1 & 2 & \\
A. stigmatus & & & & 1 & 1 & 1 & 2 & 1 & & & & \\
A. maculosus & & & & & 1 & 1 & 4 & & & & & \\
\hline
\end{tabular}

Table 7. Frequency distribution of premaxillary teeth in the species of Acestrocephalus.

\begin{tabular}{lccccccc}
\hline Premaxillary teeth & 6 & 7 & 8 & 9 & 10 & 11 & 12 \\
\hline A. sardina & & 26 & 43 & 4 & & & \\
A. boehlkei & & & & & 7 & & 1 \\
A. pallidus & & 19 & 32 & 8 & 1 & & \\
A. nigrifasciatus & 1 & 7 & 4 & & & & \\
A. acutus & 1 & 4 & 23 & & & & \\
A. stigmatus & & 3 & 2 & 1 & & & \\
A. maculosus & & 1 & 2 & 4 & & & \\
\hline
\end{tabular}

teeth on premaxilla 12 (mean=10.1, range $9-12, n=21$. Maxillary teeth 44 (mean=37.6, range 32-44, $n=21$ ), increasing in number according to increase in standard length (Fig. 6). Posterior row dentary teeth 33 (mean=26.3, range $20-33$, n=21), increasing in number ontogenetically (Fig.7). Inner row dentary teeth 11 (mean=12, range $10-14, \mathrm{n}=21$ ).

Vertebrae 39 (mean=39.6, range 39-41, $n=9)$. Total number of gill-rakers on first gill-arch 6 (mean=6.1, range 6-8, $n=21$ ).

Arrangement of muscles limiting muscular hiatus of pseudotympanum and degree of exposition of first and second pleural ribs as in $A$. sardina (compare figs. 5a and $5 \mathrm{~b}$ ).

Color in alcohol. Body light brown to pale yellowish, darker dorsally. Dorsal head and snout more densely pigmented with dark chromatophores compared to lateral part of head. Lateral body stripe broader from below dorsal-fin origin to below adipose-fin origin, narrower from dorsal-fin origin anteriorly 


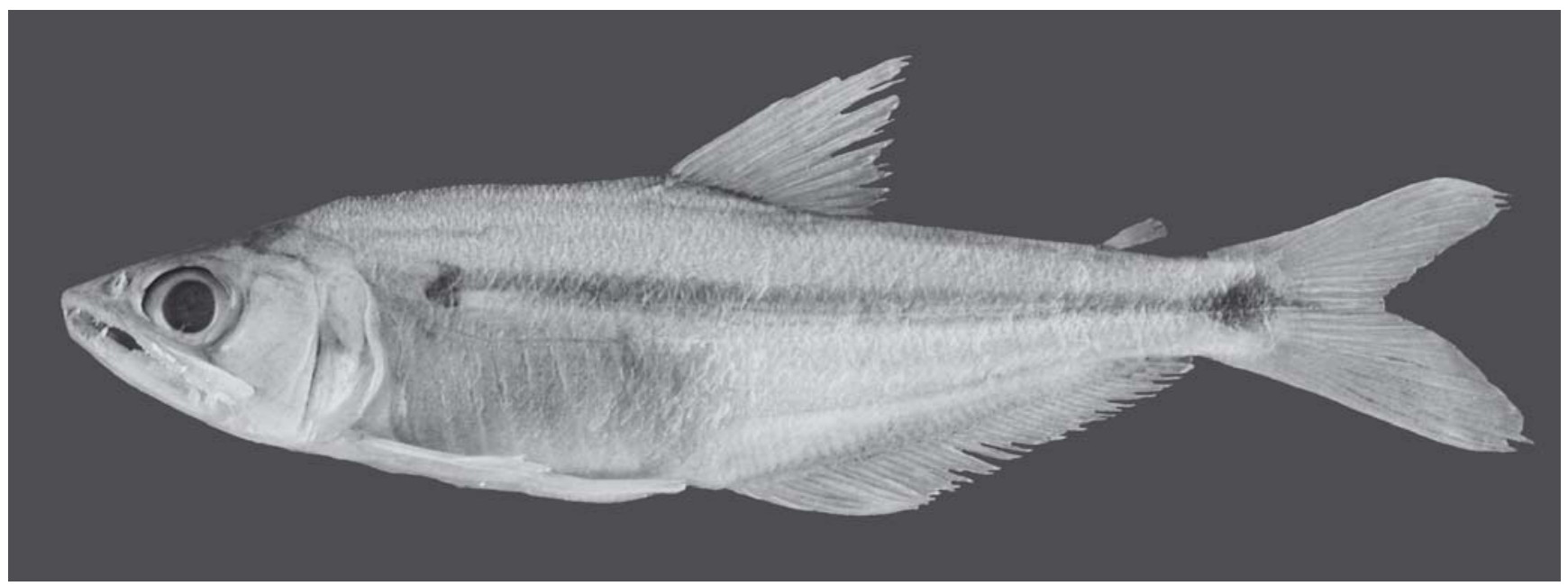

Fig. 9. Acestrocephalus boehlkei, MZUSP 12993, paratype, 85 mm SL, mature male, Río Punino, Río Napo drainage.

to upper opercle and on caudal peduncle, dark color sometimes obscured by guanine. Lateral stripe starts from behind upper opercle extending posteriorly to caudal-fin base where connecting to oblong dark blotch posteriorly extending to middle caudal-fin rays. Irregularly shaped, vertically elongated dark blotch at humeral region over anterior lateral body stripe, vertically above anterior pectoral fin. Mental area of lower jaw with diffuse dark blotch, sometimes unconspicuous or even absent. Small black dot at origin of dorsal-fin origin, extending to first unbranched dorsal-fin ray base. Dorsal, anal, and caudal fin dusky with scattered dark chromatophores along fin rays and membranes. Pectoral and pelvic fins pale with fewer dark chromatophores than other fins.

Distribution. Upper Amazon River basin in tributaries of Río Napo, Ecuador and of Río Putumayo, Peru (Fig. 8).

Remarks. Lasso \& Taphorn (1992) reported A. boehlkei from the Ventuari River, Apure River system, in the upper Río Orinoco, but emphasized that the record should be confirmed. Lasso et al. (2004), in referring to this record added that the specimens probably belong to $A$. gines $i$ Lasso \& Taphorn $(=A$. sardina) or to a species not yet described. Lasso \& Taphorn (2000) compared meristic data with specimens from the Río Ventuari to data taken from specimens of $A$. ginesi $(=A$. sardina) and suggested that the former have more branched anal-fin rays and lateral-line scales than the latter (35-38 vs 29-36 and 73-76 vs 63-71 respectively). In two specimens (MZUSP 37268) from the Río Suripa, a tributary of Río Apure, Barinas, Venezuela, the number of anal-fin rays ( 36 and 37 ) and maxillary teeth (35 and 38) are outside the range of values for A. sardina (28-33 and 40-53 respectively) and differ from $A$. boehlkei by having more posterior dentary teeth (32 and 34 vs 20-33 in A. boehlkei) and fewer small conical teeth in the outer row on the premaxilla ( 8 and 9 vs 9-12 in A. boehlkei). This strongly suggests that the specimens from the Apure River system in Venezuela, tentatively identified as $A$. ginesi $(=A$. sardina) and $A$. boehlkei probably belong to an undescribed species.
Table 8. Morphometrics of Acestrocephalus boehlkei. Standard length is expressed in $\mathrm{mm}$; measurements through head are percentages of standard length; last four entries are percentages of head length. Specimens are from: MCZ 51473 (holotype), 51474-75 (paratypes), ANSP 134500-501 (paratypes), MZUSP 12993-998 (paratypes), 38699 and USNM 216140-141 (paratypes).

\begin{tabular}{lccccc}
\hline \multicolumn{1}{c}{ Characters } & Holotype & $\mathrm{N}$ & Range & Mean & SD \\
\hline Standard length & 135.0 & 21 & $31.5-135.0$ & & \\
Body depth & 29.2 & 21 & $24.2-30.1$ & 26.7 & 1.7 \\
Snout to dorsal-fin origin & 52.2 & 21 & $48.5-53.5$ & 51.5 & 1.3 \\
Snout to pectoral-fin origin & 27.1 & 9 & $26.7-29.2$ & 28.1 & 1.0 \\
Snout to pelvic-fin origin & 42.4 & 9 & $39.5-43.0$ & 41.5 & 1.2 \\
Snout to anal-fin origin & 57.7 & 21 & $53.0-59.1$ & 56.5 & 1.5 \\
Caudal peduncle depth & 7.4 & 21 & $7.4-10.5$ & 8.5 & 0.7 \\
Caudal peduncle length & & 8 & $9.0-10.3$ & 9.8 & 0.4 \\
Pectoral-fin length & & 8 & $16.4-18.3$ & 17.3 & 0.5 \\
Pelvic-fin length & & 8 & $13.1-15.0$ & 14.5 & 0.8 \\
Dorsal-fin base length & & 8 & $10.0-12.9$ & 11.5 & 1.0 \\
Dorsal-fin height & 23.0 & 9 & $22.8-25.4$ & 24.0 & 1.1 \\
Anal-fin base length & 35.6 & 9 & $35.6-38.7$ & 36.6 & 1.0 \\
Anal-fin height & & 8 & $16.3-19.0$ & 17.2 & 1.0 \\
Eye to dorsal-fin origin & & 8 & $36.1-38.0$ & 37.0 & 0.7 \\
Dorsal-fin origin to caudal-fin base & 49.8 & 9 & $48.8-51.4$ & 50.2 & 1.0 \\
Head length & 29.6 & 21 & $29.0-31.7$ & 30.0 & 0.7 \\
Horizontal eye diameter & 31.2 & 9 & $28.1-32.5$ & 30.2 & 1.5 \\
Snout length & 28.7 & 9 & $25.7-29.2$ & 28.0 & 1.0 \\
Least interorbital width & 17.0 & 9 & $17.0-20.3$ & 18.7 & 1.1 \\
Upper jaw length & 65.0 & 9 & $62.7-67.0$ & 65.4 & 1.9 \\
\hline
\end{tabular}

Table 9. Frequency distribution of total number of gill rakers in the species of Acestrocephalus.

\begin{tabular}{lcccc}
\hline Lower limb gill rakers & 5 & 6 & 7 & 8 \\
\hline A. sardina & & 4 & 66 & 6 \\
A. boehlkei & & 6 & 1 & 1 \\
A. pallidus & & 37 & 23 & \\
A. nigrifasciatus & & & 9 & 3 \\
A. acutus & & 22 & 24 & 1 \\
A. stigmatus & 2 & 4 & & \\
A. maculosus & & & 3 & 3 \\
\hline
\end{tabular}




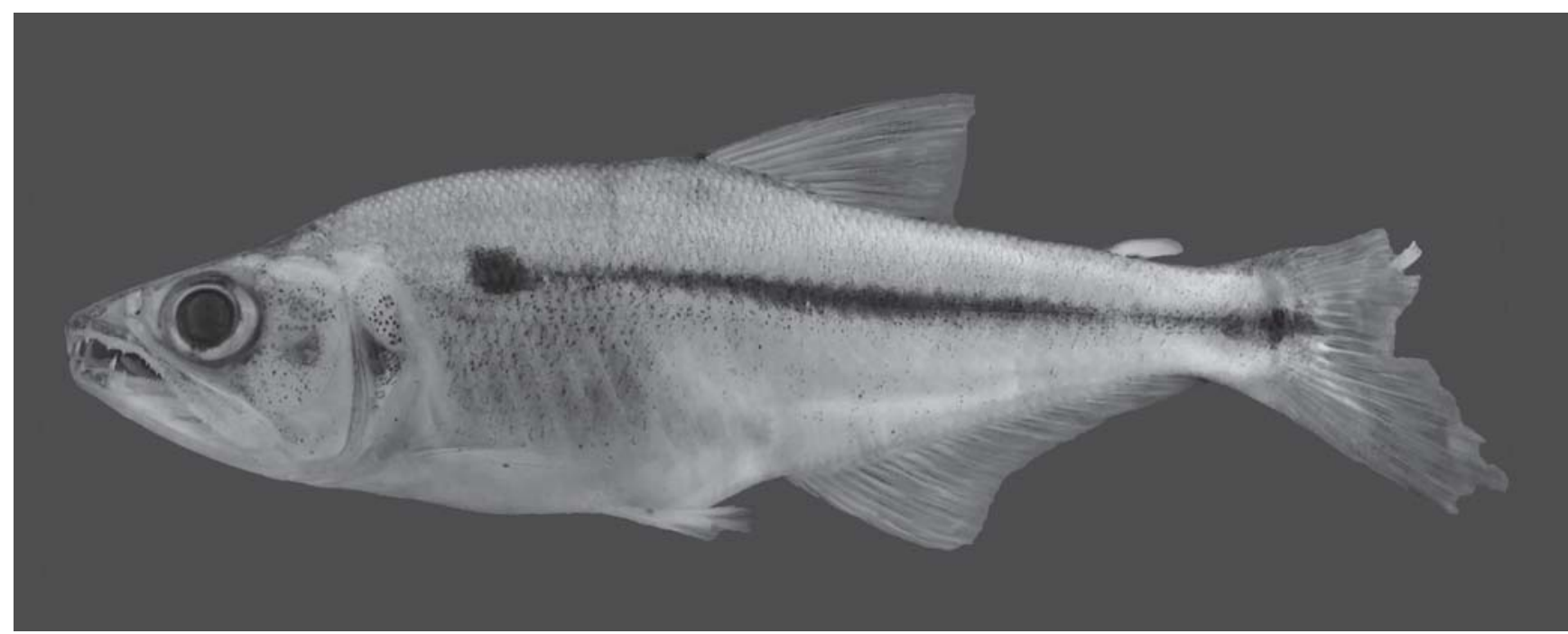

Fig. 10. Acestrocephalus maculosus, MZUSP 53974, holotype, 79 mm SL, immature female, córrego Água Parada, rio Tocantins drainage.

\section{Acestrocephalus maculosus, new species} Fig. 10

Holotype. MZUSP 53974, $79 \mathrm{~mm}$ SL, immature female, Brazil, Goiás: Minaçu, córrego Água Parada, tributary of rio do Peixe, Serra da Mesa, Miguel T. Rodrigues et al., May 1996.

Paratypes. MZUSP 90162, 1, $72 \mathrm{~mm}$ SL, taken with holotype. MNRJ 12714, 1, 42.3 mm SL, Brazil, Goiás: Uruaçu, rio Palmeira, left bank tributary of rio Maranhão, upper rio Tocantins basin, G.W. Nunan and D.F. Moraes Jr., 17 October 1985; MNRJ 12657 , 3, 44-62 mm SL, Niquelândia: rio do Peixe, right bank tributary of rio Maranhão, upper Tocantins basin, G.W. Nunan \& D.F. Moraes Jr, 08 October 1985.

Diagnosis. Acestrocephalus maculosus has a dark blotch at the humeral region, a character shared only with $A$. boehlkei and $A$. stigmatus. In the diagnosis of $A$. boehlkei the differences among these species are discussed. Acestrocephalus maculosus can be easily distinguished from $A$. stigmatus by the number of anal-fin rays (25-27 vs 29-31), and total number of gill-rakers (7-8 vs 5-6). See Tables 4 and 9. The general structure of the pseudotympanum of $A$. maculosus (Fig. 5c) is quite peculiar and different from that of $A$. stigmatus (Fig. 5d) and all the other species of Acestrocephalus examined (Figs. 5a, b, e, fand g). In A. maculosus the muscular hiatus is very reduced as the result of the great development of the obliquus superioris muscle covering the anterior portion of the swim bladder. As a consequence, the opening anterior to first pleural rib, this and the second pleural rib as well as the obliquus inferioris muscle are not visible.

Description. Morphometrics of holotype and paratypes presented in table 10. Body relatively small ( $\mathrm{SL}=42.3-79 \mathrm{~mm}$ ). Body form, dorsal and ventral body profiles, shape of snout and mouth and extension of maxilla as in A. sardina.

Dorsal-fin rays ii, 9 in all specimens, $n=6$, including holotype. Posterior most ray unbranched, $n=6$. Adipose fin
Table 10. Morphometrics of Acestrocephalus maculosus. Standard length is expressed in mm; measurements through head are percentages of standard length; last four entries are percentages of head length. Specimens are from: MZUSP 53974, 90162, MNRJ 12714, 12657.

\begin{tabular}{lccccc}
\hline \multicolumn{1}{c}{ Characters } & Holotype & N & Range & Mean & SD \\
\hline Standard length & 79.0 & 6 & $42.3-79.0$ & & \\
Body depth & 29.7 & 6 & $27.2-29.7$ & 28.4 & 1.3 \\
Snout to dorsal-fin origin & 54.4 & 6 & $52.7-55.5$ & 54.4 & 0.9 \\
Snout to pectoral-fin origin & 31.6 & 6 & $31.3-32.1$ & 31.4 & 0.1 \\
Snout to pelvic-fin origin & 46.3 & 6 & $45.4-46.3$ & 46.0 & 0.6 \\
Snout to anal-fin origin & 61.0 & 6 & $59.3-61.4$ & 60.3 & 0.8 \\
Caudal peduncle depth & 8.8 & 6 & $8.0-9.3$ & 8.7 & 0.4 \\
Caudal peduncle length & 11.4 & 6 & $11.0-12.5$ & 11.6 & 0.6 \\
Pectoral-fin length & 17.3 & 6 & $17.2-18.5$ & 17.7 & 0.6 \\
Pelvic-fin length & 15.2 & 6 & $15.2-16.7$ & 15.7 & 0.5 \\
Dorsal-fin base length & 12.4 & 6 & $11.3-12.5$ & 12.0 & 0.4 \\
Dorsal-fin height & 25.3 & 6 & $24.3-26.2$ & 25.1 & 1.6 \\
Anal-fin base length & 30.7 & 6 & $30.7-33.7$ & 31.6 & 1.5 \\
Anal-fin height & 16.9 & 6 & $16.3-19.6$ & 18.0 & 1.5 \\
Eye to dorsal-fin origin & 38.0 & 6 & $37.5-38.8$ & 38.2 & 0.5 \\
Dorsal-fin origin to caudal-fin base & 50.0 & 6 & $47.7-51.3$ & 49.5 & 1.3 \\
Head length & 33.0 & 6 & $31.5-33.1$ & 32.7 & 0.9 \\
Horizontal eye diameter & 29.6 & 6 & $29.1-31.7$ & 30.5 & 0.9 \\
Snout length & 28.0 & 6 & $27.7-28.8$ & 28.2 & 0.2 \\
Least interorbital width & 19.2 & 6 & $19.2-21.0$ & 19.8 & 0.6 \\
Upper jaw length & 65.4 & 6 & $63.5-66.4$ & 65.0 & 0.9 \\
\hline
\end{tabular}

present. Anal-fin rays iv,27 (iv or v, usually iv unbranched, branched rays mean $=26.5$, range $25-27, n=6$, posterior ray split to its base and counted as 1). Moderately developed anterior anal-fin lobe including anterior unbranched rays and first 6-7 branched rays. No hooks on anterior rays of two sexually mature males (MZUSP 90162, $92 \mathrm{~mm}$ SL and MNRJ 12657, 62 $\mathrm{mm} \mathrm{SL}$ ). Pectoral-fin rays i, 14 (anterior branched ray $\mathrm{i}, \mathrm{n}=6$ ) branched rays mean $=14$, range $13-15, n=6$. Posterior tips of longest pectoral-fin rays reaching scarcely beyond pelvic-fin origin. Pelvic-fin rays $\mathrm{i}, 7, \mathrm{n}=6$. No hooks on pelvic-fin rays of sexually mature males. Distal tips of longest pelvic-fin rays extending slightly beyond posterior border of anus, falling 


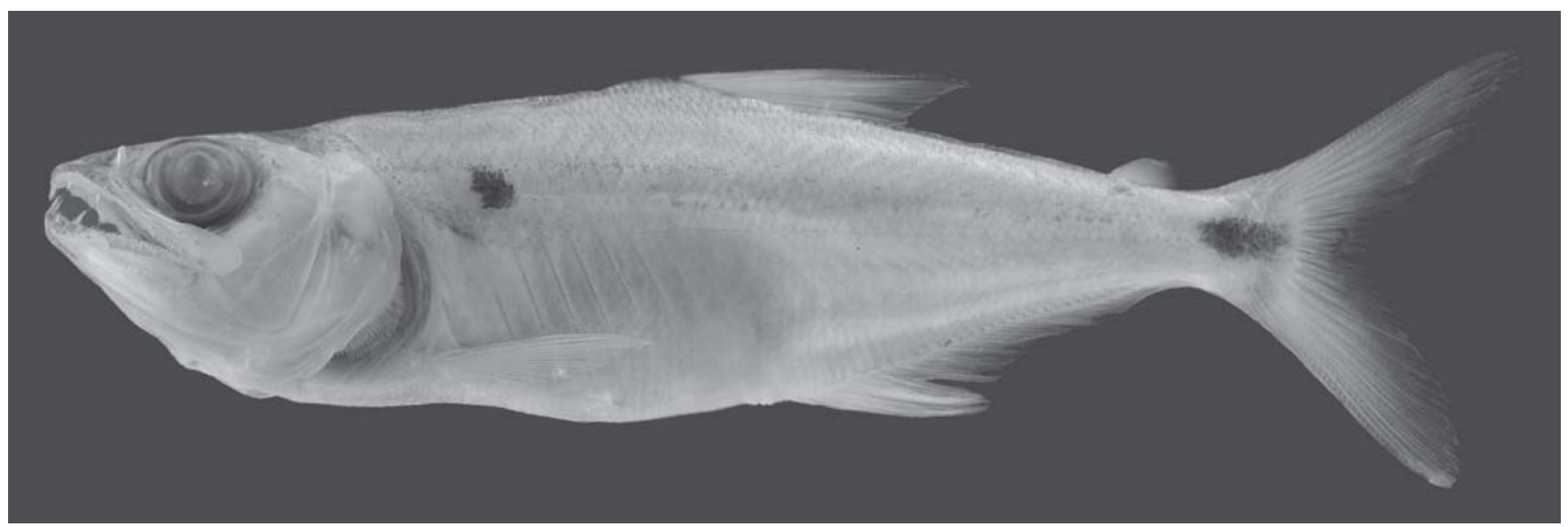

Fig. 11. Acestrocephalus stigmatus, MNRJ 24997, paratype, $82 \mathrm{~mm} \mathrm{SL}$, mature female, rio das Mortes, rio Araguaia basin.

short of origin of anal fin. Principal caudal-fin ray count 10/9, $\mathrm{n}=6$.

Lateral line complete, perforated scales 73 (mean $=72.5$, range $71-73, n=6$. Scale rows above lateral line $14, n=6$. Scale rows below lateral line $12, n=6$. Scale rows around caudal peduncle $23, \mathrm{n}=6$.

Shape, size and arrangement of premaxillary, maxillary and dentary teeth as in $A$. sardina. Outer row small conical teeth on premaxilla 9 (mean $=8.5$, range $7-9, n=6)$. Maxillary teeth 35 (mean $=37$, range $35-40, n=6$ ), possibly increasing in number with an increase in standard length although no clear evidence detected from data taken from type series. Posterior dentary teeth 24 (mean $=25.5$, range $35-40, n=6$ ), also probably increasing in number ontogenetically. Inner row dentary teeth 12 (mean=12.8, range $12-14, \mathrm{n}=6)$.

Vertebrae 41 (mean 40.2, range 39-41, $\mathrm{n}=6$ ). Total number of gill-rakers on first gill-arch 7 (mean=7.5, range 7-8, $\mathrm{n}=6$ ).

Obliquus superioris muscle greatly developed, reducing muscular hiatus of pseudotympanum to small slit and completely covering cavity anterior to first pleural rib, this, second pleural rib and obliquus inferioris muscle (Fig. 5c).

Color in alcohol. Body color light brown to pale yellow, head and trunk profusely covered with dark chromatophores. Chromatophores on head mostly concentrated dorsally, as well as snout, anterior border of lower jaw, maxilla, circumorbital bones and opercle. Dark chromatophores especially abundant along free edge of scales in both dorsal and anterior ventral parts of trunk. Dark irregularly shaped blotch at humeral region, slightly longer than deep. Dark lateral stripe extending from posterior part of humeral dark blotch to caudal peduncle joining oblong dark blotch at caudal-fin base, dark color extending to bases of middle caudal-fin rays. Lateral body stripe wider from dorsal-fin origin to adipose-fin origin, narrower from dorsal-fin origin anteriorly to humeral blotch and on caudal peduncle. Mental area of lower jaw with diffuse dark blotch. Dorsal-fin origin with black spot extending to base of first unbranched dorsal-fin ray. Fins pale with scattered dark chromatophores more abundant on dorsal and caudal fins.
Distribution. Acestrocephalus maculosus is known only from tributaries of the upper Tocantins (Fig. 8).

Etymology. The species name maculosus, adjective, comes from Latin meaning spotted. It is in reference to the dark spots and stripes on the body of this species.

\section{Acestrocephalus stigmatus, new species} Fig. 11

Acestrocephalus sardina; Menezes, 1976: 39 (in part, only specimen from rio das Mortes, MZUSP 10422).

Holotype. MNRJ 28718 (80 mm SL), mature female, Brazil, Mato Grosso: Nova Xavantina, rio das Mortes, rio Araguaia basin, $14^{\circ} 40^{\prime} 9^{\prime \prime S}, 52^{\circ} 21^{\prime} 12^{\prime \prime W}$, by P.A. Buckup, A. Aranda, F. Silva and C. Figueiredo, 29 January 2002.

Paratypes. MNRJ 24997, 1, 82 mm SL, taken with holotype. MNRJ 17610, 2, 78.5 and $93 \mathrm{~mm}$ SL, Goiás: Colinas do Sul, pools in rio Tocantins below reservoir of Serra da Mesa, $13^{\circ} 49^{\prime} \mathrm{S}, 48^{\circ} 11^{\prime} \mathrm{W}$, by D.F. Moraes, D.A. Halboth, O.T. Oyakawa et al.,1996. MZUSP 10422, 98 mm SL, Mato Grosso: rio das Mortes, Xavantina, $14^{\circ} 40^{\prime} \mathrm{S}, 52^{\circ} 21^{\prime} \mathrm{W}$, by RS/RGS Xavantina Expedition, March 1974; MZUSP 62846, 1, 92.5 mm SL, Nova Xavantina: rio das Mortes in Capitariguara, south of Nova Xavantina, 14³0'22"S, 51 '51'89", by C.H. Melo, A.M. Batistella and H.A. Silva, October, 1997.

Non-type material. MZUSP 89811, 1, 73.4 mm SL, Brazil, Mato Grosso: Paranatinga, rio Culuene, rio Xingu drainage, $13^{\circ} 49^{\prime} 00^{\prime \prime S}$, $53^{\circ} 15^{\prime} 00^{\prime \prime W}$; MZUSP 88699, 1, 59 mm SL, Gaúcha do Norte: rio Curisevo, rio Xingu drainage, $13^{\circ} 12^{\prime} 58^{\prime \prime} \mathrm{S}, 53^{\circ} 29^{\prime} 53^{\prime \prime} \mathrm{W}$.

Diagnosis. Acestrocephalus stigmatus can be distinguished from all congeners except $A$. boehlkei and A. maculosus by the presence of a dark humeral blotch. From $A$. boehlkei it differs in having fewer anal-fin rays (29-31 vs 34-36) and fewer scale rows around caudal peduncle (22-23 vs 25). It has more anal-fin rays (29-31) than $A$. maculosus (25-27). The muscular hiatus of the pseudotympanum in A. stigmatus (Fig. $5 \mathrm{~d}$ ) is narrower than that of $A$. boehlkei, but much more developed than that of A. maculosus (Fig. 5c). 
Description. Morphometrics of the holotype and additional specimens presented in Table 11. Meristic and morphometric data based on two lots from two widely separate localities, however no statistical differences were found between samples. Body moderately small ( $\mathrm{SL}=78.5-98 \mathrm{~mm}$ ). Body form, dorsal and ventral body profiles, shape of snout and mouth and extension of maxilla as in A. sardina.

Dorsal-fin rays ii, 9 in all specimens, $\mathrm{n}=6$, including holotype. Posterior most ray unbranched, $n=6$. Adipose fin present. Anal-fin rays iv, 30 (unbranched rays iv, $n=6$, branched rays mean $=30$, range $29-31, n=6$, posterior ray split to its base and counted as 1). Moderately developed anterior anal-fin lobe including anterior unbranched rays and first 7-8 branched rays. Two sexually mature males (MNRJ 17610) with bilateral hooks on posterior anterior branched rays. One specimen $(93$ $\mathrm{mm} \mathrm{SL}$ ) has 10 hooks on second branched ray, 9 on third, 7 on fourth and 2 on fifth. Pectoral-fin rays i,13 (anterior unbranched ray $i, n=6$, branched rays mean $=13.3$, range $13-14, n=6$ ). Posterior tips of longest pectoral-fin rays reaching to about one third of pelvic fin length. Pelvic-fin rays i, $7, n=6$. No hooks on pelvic-fin rays of sexually mature males. Distal tips of longest pelvic-fin rays reaching posterior border of anus. Principal caudal-fin ray count 10/9, $\mathrm{n}=6$.

Lateral line complete, perforated scales 70 (mean $=72.1$, range $70-74, \mathrm{n}=6$ ). Scale rows above lateral line 13 (mean=13.3, range $13-14, \mathrm{n}=6$ ). Scale rows below lateral line 11 (mean=11.5, range $11-12, \mathrm{n}=6$ ). Scale rows around caudal peduncle 22 (mean=22.5, range 22-23, $\mathrm{n}=6$ ).

Shape size and arrangement of teeth on premaxilla, maxilla and dentary as in $A$. sardina. Outer row small conical teeth on premaxilla $8($ mean $=7.6$, range $7-9, n=6)$. Maxillary teeth 39

Table 11. Morphometrics of Acestrocephalus stigmatus. Standard length is expressed in $\mathrm{mm}$; measurements through head length are percentages of standard length; last four entries are percentages of head length. Specimens are from MNRJ 28718 (holotype), 17610 (paratypes), MZUSP 10422, and 62846 (paratypes).

\begin{tabular}{lccccc}
\hline \multicolumn{1}{c}{ Characters } & Holotype & N & Range & Mean & SD \\
\hline Standard length & 80.0 & 6 & $78.5-98.0$ & & \\
Body depth & 30.8 & 5 & $24.8-30.8$ & 28.1 & 2.1 \\
Snout to dorsal-fin origin & 53.2 & 6 & $50.0-53.2$ & 52.0 & 1.2 \\
Snout to pectoral-fin origin & 31.2 & 6 & $29.3-31.2$ & 30.1 & 0.6 \\
Snout to pelvic-fin origin & 45.0 & 6 & $43.5-45.4$ & 44.8 & 0.6 \\
Snout to anal-fin origin & 61.2 & 6 & $58.6-63.0$ & 61.3 & 1.5 \\
Caudal peduncle depth & 8.0 & 6 & $7.6-8.2$ & 8.0 & 0.2 \\
Caudal peduncle length & 9.1 & 6 & $9.0-10.2$ & 9.5 & 0.5 \\
Pectoral-fin length & 19.1 & 6 & $17.2-19.2$ & 18.4 & 0.8 \\
Pelvic-fin length & 15.0 & 6 & $14.6-15.0$ & 14.8 & 0.2 \\
Dorsal-fin base length & 12.8 & 6 & $10.0-13.1$ & 12.7 & 0.4 \\
Dorsal-fin height & 25.3 & 6 & $22.4-25.8$ & 24.2 & 1.5 \\
Anal-fin base length & 34.3 & 6 & $32.0-34.4$ & 33.2 & 1.0 \\
Anal-fin height & 18.5 & 6 & $17.2-18.5$ & 17.8 & 0.5 \\
Eye to dorsal-fin origin & 36.7 & 6 & $35.4-37.3$ & 36.3 & 0.7 \\
Dorsal-fin origin to caudal-fin base & 52.8 & 6 & $50.5-53.3$ & 52.1 & 1.1 \\
Head length & 31.2 & 6 & $30.4-31.3$ & 31.0 & 0.3 \\
Horizontal eye diameter & 32.8 & 6 & $30.5-33.7$ & 32.4 & 1.1 \\
Snout length & 28.0 & 6 & $28.0-29.0$ & 28.4 & 0.4 \\
Least interorbital width & 18.0 & 6 & $17.5-18.7$ & 18.2 & 0.4 \\
Upper jaw length & 67.2 & 6 & $65.7-67.3$ & 66.8 & 0.6 \\
\hline
\end{tabular}

(mean=39.6, range 39-40, $n=6$ ). Posterior row dentary teeth 35 (mean $=35.6$, range 33-40, $n=6$ ). Inner row dentary teeth 10 (mean $=10.5$, range $9-12, \mathrm{n}=6$.

Vertebrae 38 (mean $=38.4$, range $38-39, \mathrm{n}=6$ ). Total number of developed gill-rakers on first gill-arch 6 (mean $=5.6$, range $5-6, \mathrm{n}=6)$.

Muscular hiatus of pseudotympanum longer than deep, but arrangement of associated muscles without major modifications (Fig. 5d). First and second pleural ribs slightly less exposed than in A. sardina (Compare figs. 5d and 5a) and obliquus inferioris muscle visible.

Color in alcohol. Body pale yellow darker dorsally especially on head and snout. Premaxilla and anterior maxilla densely pigmented with dark chromatophores. Dark chromatophores also concentrated along lower jaw upper edge extending onto bases of anterior canines. Free edges of scales on dorsolateral trunk bordered with row of dark chromatophores. Dark blotch at humeral region irregularly shaped, deeper than long. Lateral body stripe represented by thin layer of dark chromatophores, unconspicuous in some specimens sometimes obscured by guanine pigment. Lateral body stripe extending from behind dorsal opercle across humeral dark blotch to caudal peduncle. Oblong dark blotch encompassing posterior caudal peduncle and caudal-fin base, extending to bases of middle caudal-fin rays. Mental area of lower jaw with diffuse dark patch of dark chromatophores. Dorsal-fin origin with black spot extending onto base of first unbranched ray. All fins pale with very few chromatophores except dorsal and pectoral fins where dark chromatophores are mostly concentrated along proximal half of first unbranched ray (pectoral) or along entire length of first two unbranched rays (dorsal).

Distribution. Specimens of this species are known from the rio Tocantins, rio das Mortes, a tributary of rio Araguaia (Fig. 8 ) and from the rio Xingu. It is sympatric with A. maculosus and $A$. acutus in the upper Tocantins basin.

Remarks. The two specimens from the rio Xingu drainage, not included in the type series did not show significant differences with respect to the type series, but additional specimens are needed for a more thorough evaluation.

Etymology. The species name stigmatus, adjective, is derived from the Greek word "stigma" meaning mark, spot, in reference to the dark spot found at the humeral region of this species.

\section{Acestrocephalus nigrifasciatus, new species} Fig. 12

Holotype. MCP 30420 (83 mm SL), Brazil, Mato Grosso: Porto

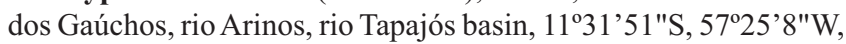
by R.E. Reis, L.R. Malabarba, E.H.L. Pereira, V. A. Bertaco \& A.R. Cardoso, 19 Jan 2002. 


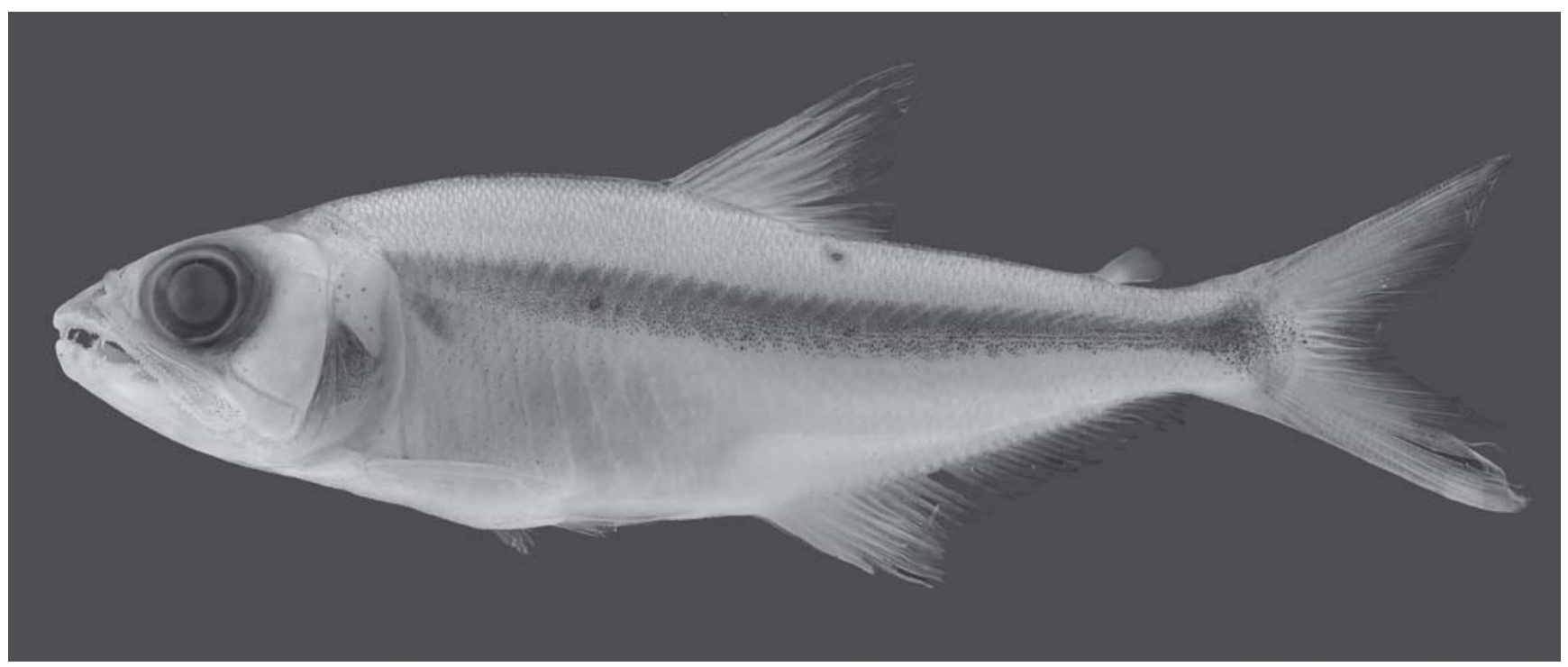

Fig. 12. Acestrocephalus nigrifasciatus, MCP 30420, holotype, mature male, 83 mm SL, rio Arinos, rio Tapajós drainage.

Paratypes. MCP 39930, 9, 64-93 mm SL, taken with holotype. MZUSP 62845, 1, 85 mm SL, Brazil, Mato Grosso, rio Juruena, about 1 kilometer above mouth of rio Arinos, by F.A. Machado et al., 25-26 July 1997; MZUSP 62847, 1, 63 mm SL, ilha do Túlio, rio Arinos about 3 kilometers before emptying into rio Juruena, by F.A. Machado et alii, 24-25 July 1997.

Diagnosis. Acestrocephalus nigrifasciatus has the same color pattern (Fig. 12) and eye size (Fig. 4) of A. sardina (Fig. 3), distinct from all other species of Acestrocephalus. A. nigrifasciatus, however, has more scale rows above (13-14 vs 10-12) and below (12-13 vs 10-12) lateral line. The muscular hiatus of the pseudotympanum in A. nigrifasciatus (Fig. 5e) is longer and narrower than that of $A$. sardina (Fig. 5a) and the fibers of the obliquus inferioris muscle are not visible as in the latter species.

Description. Morphometrics of holotype and additional specimens presented in Table 12. Body moderately large ( $\mathrm{SL}=64.0-93.0 \mathrm{~mm}$ ). Body form, dorsal and ventral body profiles, shape of snout and mouth and extension of maxilla as in A. sardina.

Dorsal fin rays ii, 9 in all specimens, $\mathrm{n}=12$, including holotype. Posterior most ray unbranched, $n=12$. Adipose fin present. Anal-fin rays iv,28 (iv or v, usually iv unbranched, branched rays mean $=29$, range $27-31, n=12$, posterior ray split to its base and counted as 1). Moderately developed anal-fin lobe including anterior unbranched rays and first 6-7 branched rays. Anal fin of six sexually mature males with bilateral hooks on posterior anterior branched rays. One specimen (MCP $30420,79 \mathrm{~mm} \mathrm{SL}$ ) has the first 15 branched rays bearing hooks. Number of hooks per ray decreasing from anterior most to posterior most rays ( 8 hooks on first, 17 on second, 7 on seventh, 3 on 13 th and 1 on 15 th). Pectoral-fin rays i, 15 (anterior unbranched rays $i, n=12$, branched rays mean 14.6 , range $14-15, n=12)$. Posterior tips of longest pectoral-fin rays reach-
Table 12. Morphometrics of Acestrocephalus nigrifasciatus. Standard length is expressed in mm; measurements through head length are percentages of standard length; last four entries are percentages of head length. Specimens are from: MCP 30420 (holotype), 39930, MZUSP 62847, 62845 (paratypes).

\begin{tabular}{lccccc}
\hline \multicolumn{1}{c}{ Characters } & Holotype & $\mathrm{N}$ & Range & Mean & SD \\
\hline Standard length & 83.0 & 12 & $64.0-93.0$ & & \\
Body depth & 27.4 & 10 & $27.0-30.7$ & 28.6 & 1.2 \\
Snout to dorsal-fin origin & 51.5 & 12 & $50.0-52.0$ & 50.5 & 0.9 \\
Snout to pectoral-fin origin & 29.5 & 12 & $28.5-30.8$ & 29.7 & 0.6 \\
Snout to pelvic-fin origin & 44.3 & 12 & $43.0-44.7$ & 43.9 & 0.6 \\
Snout to anal-fin-origin & 60.2 & 12 & $58.1-61.4$ & 59.6 & 1.1 \\
Caudal peduncle depth & 8.2 & 12 & $7.6-8.6$ & 8.0 & 0.3 \\
Caudal peduncle length & 10.0 & 12 & $9.6-10.8$ & 10.3 & 0.3 \\
Pectoral-fin length & 17.7 & 12 & $16.7-18.8$ & 17.8 & 0.6 \\
Pelvic-fin length & 13.6 & 12 & $13.0-15.6$ & 14.1 & 0.8 \\
Dorsal-fin base length & 12.4 & 12 & $11-13.7 .5$ & 12.5 & 0.5 \\
Dorsal-fin height & 22.6 & 12 & $21.6-24.8$ & 23.3 & 1.2 \\
Anal-fin base length & 33.7 & 12 & $32.5-34.8$ & 33.6 & 0.7 \\
Anal-fin lobe length & 16.0 & 12 & $15.1-18.0$ & 16.2 & 0.9 \\
Eye to dorsal-fin origin & 34.1 & 12 & $32.6-35.0$ & 33.7 & 0.7 \\
Dorsal-fin origin to caudal-fin base & 49.4 & 12 & $49.4-52.5$ & 51.1 & 1.1 \\
Head length & 32.5 & 12 & $30.4-33.6$ & 32.1 & 0.9 \\
Horizontal eye diameter & 34.4 & 12 & $32.6-36.5$ & 34.7 & 1.3 \\
Snout length & 29.6 & 12 & $27.5-30.8$ & 29.0 & 0.9 \\
Least interorbital width & 18.5 & 12 & $17.0-20.0$ & 18.5 & 1.0 \\
Upper jaw length & 65.5 & 12 & $64.7-67.7$ & 66.4 & 1.0 \\
\hline
\end{tabular}

ing slightly beyond pelvic-fin origin. Pelvic-fin rays $\mathrm{i}, 7, \mathrm{n}=12$. No hooks on pelvic-fin rays of sexually mature males. Distal tips of longest pelvic-fin rays reaching anterior border of anus. Principal caudal-fin ray count $10 / 9, \mathrm{n}=12$.

Lateral line complete, perforated scales 74 (mean $=72.6$, range $70-75, n=12)$. Scale rows above lateral line 13 (men=13.4, range $13-14, n=12$ ). Scale rows below lateral line 13 (mean=12.6, range $12-13, n=12)$. Scale rows around caudal peduncle 23 (mean=23.1, range $=23-24, \mathrm{n}=12$ ).

Shape, size and arrangement of teeth on premaxilla, maxilla and dentary as in A. sardina. Outer row small conical 


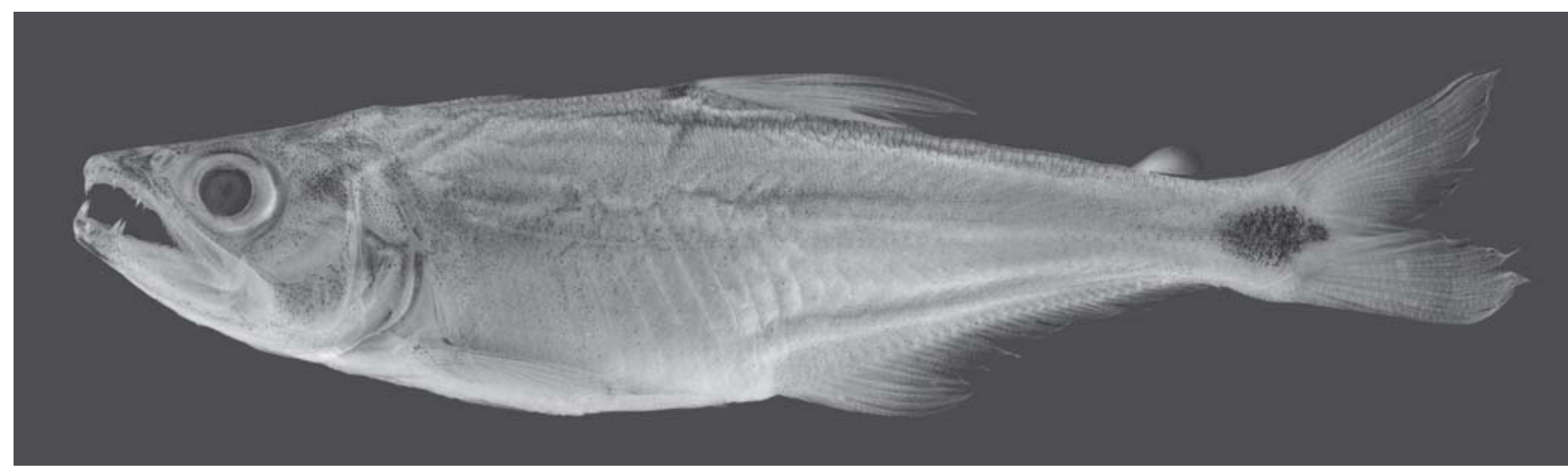

Fig. 13. Acestrocephalus acutus, MZUSP 31650, holotype, mature female, $80 \mathrm{~mm}$ SL, igarapé do Cinzento, rio Itacaiunas, rio Tocantins drainage.

teeth on premaxilla 7 (mean $=7.2$, range $6-8, n=12$ ). Maxillary teeth 41 (mean=42.4, range 40-46, $n=12$ ), with no clear tendency to increase in number with an increase in standard length (Fig. 6). Posterior row dentary teeth 31 (mean=30.1, range $27-34, \mathrm{n}=12$ ). Inner row dentary teeth 11 (mean=10.2, range $8-12, \mathrm{n}=12)$.

Vertebrae 37 (mean=37.4, range 37-38, $n=11)$. Total number of gill rakers on first gill-arch 8 (mean=7.2, range 7-8, $n=12$ ).

Muscular hiatus of pseudotympanum (Fig. 5f) reduced, much longer than deep, exposed first pleural rib scarcely visible, second pleural rib slightly more visible, but obliquus inferioris muscle fibers entirely covered by ventral fibers of obliquus superioris.

Color in alcohol. Similar to that of $A$. sardina, but dark lateral body stripe broader along entire length (compare Figs. 3 and 12) darker anteriorly; diffuse dark blotch on mental area of lower jaw less conspicuous.

Distribution. Acestrocephalus nigrifasciatus is known from the rios Arinos and Juruena, and rio Tapajós basin (Fig. 8) in the state of Mato Grosso.

Etymology. The first part of the species name niger is Latin for black and the second part fasciatus is also derived from the Latin word "fascia" meaning band or stripe, in reference to the dark lateral body stripe of this species. Both names are adjectives.

\section{Acestrocephalus acutus, new species} Fig. 13

Holotype. MZUSP 31650, mature female, 80 mm SL, Brazil, Pará: Caldeirão, igarapé do Cinzento, rio Itacaiúnas, by Michael Goulding, November, 1983.

Paratypes. MZUSP 40830, 3, 73.5-101.0 mm SL, Brazil, Tocantins: Arraias, rio Bezerra near bridge on road GO-112, rio Tocantins drainage, by José C. Oliveira, 8 January 1989; MZUSP 82105, 3, 50-68 mm SL, Porto Alegre do Tocantins: rio Manuel Alves da Natividade, rio Tocantins drainage, by Cristiano R. Moreira, J.C. Nolasco, and M. Ávila, 20 July 2002, MZUSP 40691, 6, 51.5-75 mm SL, Goiás: Monte Alegre de Goiás, rio Bezerra, right bank tributary of rio Paraná, rio Tocantins drainage, by José C. Oliveira and Wilson, J.M. Costa, 22 September 1989; MCP 15855, 1, 85 mm SL, Niquelândia: ribeirão da Laje, rio Tocantins drainage, by R.E. Reis, J. Pezzi, E. Pereira and L.A. Porto, 17 July 1992; MNRJ 28716, 1, 83 mm SL, Niquelândia: rio do Peixe, right bank tributary of rio Maranhão, rio Tocantins drainage, $14^{\circ} 28^{\prime} \mathrm{S}, 48^{\circ} 45^{\prime} \mathrm{W}$, by Gustavo Nunan and D.F. Moraes, 08 October 1985; MNRJ 17612, 28, 39.4-98 mm SL, Colinas do Sul: pools in rio Tocantins below reservoir of Serra da Mesa, $13^{\circ} 49^{\prime} \mathrm{S}, 48^{\circ} 11^{\prime} \mathrm{W}$, by D.F. Moraes, D.A. Halboth, O.T. Oyakawa et alii, 1996; MNRJ 28717, 1, 103.5 $\mathrm{mm}$ SL, Minaçu, Cavalcante: rio Tocantins in Serra da Mesa, $14^{\circ} 40^{\prime} 9^{\prime \prime S}, 52^{\circ} 21^{\prime} 12^{\prime \prime W}$, by P. Buckup, A. Aranda, F. Silva and C. Figueiredo, 29 January 2002; MNRJ 18315, 2, 28.5 and $72.0 \mathrm{~mm}$ SL, Colinas do Sul: pools in left bank of rio Tocantins above Ponte Rubião, by D.F. Moraes, D.A. Halboth, O.T. Oyakawa et al., 28 October 1996; MNRJ 21136, 1, 78 mm SL, Formosa: tributaries of rio Paraná, north of Formosa, 15²8'52"S, 47²0'33"W, by F.A.G. Melo, P.A. Buckup and M.R.S. Melo, 21 November 2000.

Non type material. MZUSP 63009, 4, 87-96.5 mm SL, Brazil, Mato Grosso: Paranatinga, rio Teles Pires, fazenda do Antônio Bezerra, 14²26'S,543'' W, November 1997; MCP 30 485, 2, 76 and $82 \mathrm{~mm}$ SL, Nova Canaã do Norte: rio Tels Pires on road between Nova Canaã do Norte and Alta Floresta, 10¹4'17"S, 55 48'28"W, 22 January 2002; MCP 30481, 1, 39.3 mm SL, Tabaporã: rio Teles Pires on road MT-220 between Sinop and Porto dos Gaúchos, 11³9’15"S, 55³9’18"W, 20 January 2002.

Diagnosis. Among the species of Acestrocephalus without dark humeral blotch, $A$. acutus can be distinguished from $A$. sardina and $A$. nigrifasciatus by having a smaller eye (28.031.7 vs 32.6-36.5 in A. nigrifasciatus and 31.3-37.4 in A. sardina; compare tables 3,12 and 13) and an oblong dark blotch at caudal base instead of the triangular dark blotch present on the caudal base of those two species (compare Figs. 3, 9, and 12). It differs from $A$. pallidus by the presence of the oblong dark blotch $v s$ absence of dark blotch at caudal base. The shape of the muscular hiatus of the pseudotympanum and the muscular arrangement around it in A. acutus and A. pallidus are also different (compare figs. $5 \mathrm{f}$ and $5 \mathrm{~g}$ ). Acestrocephalus acutus differs from $A$. anomalus by having more teeth in the posterior row on dentary (28-36 vs 23-28) and fewer teeth in the external tooth row on premaxilla (6-8 vs 8-11). 
Description. Morphometrics of holotype and additional specimens presented in Table 13. Meristic and morphometric data based on all lots in type series. No statistical differences found among population samples studied. Body relatively large ( $\mathrm{SL}=50-103.5 \mathrm{~mm}$ ). Body form, dorsal and ventral body profiles, shape of snout and mouth and extension of maxilla as in A. sardina.

Dorsal-fin rays ii, 9 in all specimens, $n=47$, including holotype. Posterior most ray unbranched, $n=47$. Adipose fin present. Anal-fin rays iv,31 (iv or v, usually iv unbranched, branched rays mean $=32$, range $29-35, n=47$, posterior ray split to its base and counted as 1). Modestly developed anterior anal-fin lobe including anterior unbranched rays and first 8-9 branched rays. Three sexually mature males with bilateral hooks on posterior anterior branched rays. One sexually mature male (MCP 15855, $85 \mathrm{~mm} \mathrm{SL}$ ) has hooks on first 14 branched anal-fin rays, number of hooks per ray increasing from first (5) to sixth (14) then decreasing from seventh (12) through tenth (5), 13th (3) and 14th (1). Pectoral-fin rays i,12 (anterior unbranched ray $\mathrm{i}, \mathrm{n}=47$, branched rays mean 12.7 , range $11-14$, $\mathrm{n}=47$ ). Posterior tips of longest pectoral-fin rays reaching to about one third of pelvic-fin length. Pelvic-fin rays i, 7, $n=47$. No pelvic-fin ray hooks on sexually mature males. Distal tips of longest pelvic-fin rays reaching anterior border of anus. Principal caudal-fin ray count $10 / 9, \mathrm{n}=47$.

Lateral line complete, perforated scales 74 (mean $=73.8$, range $70-77, \mathrm{n}=46$ ). Scale rows above lateral line 13 (mean=12.9, range $12-14, n=46)$. Scale rows below lateral line 11 (mean=11.4, range $10-14, \mathrm{n}=46$ ). Scale rows around caudal peduncle 23 (mean=22.8, range 22-24, $\mathrm{n}=46$ ).

Shape, size and arrangement of teeth on premaxilla, maxilla and dentary as in A. sardina. Outer row small conical teeth on premaxilla $9($ mean $=8.3$, range $7-10, n=47)$. Maxillary teeth $36($ mean $=33.6$, range $28-38, n=47)$. Fig. 6 suggests a tendency for the number of maxillary teeth to increase in number according to an increase in standard length. Posterior row dentary teeth 33 (mean $=30.5$, range $28-36, n=47$ ), tending to increase in number with an increase in standard length (Fig.7). Inner row dentary teeth 11 (mean=11.2, range 10-13, $\mathrm{n}=47$ ).

Vertebrae 38 (mean=38.7, range $37-39, n=28$ ). Total number of gill-rakers on first gill-arch 7 (mean=6.6, range 6-8, $n=47$ ).

Branchiostegal rays 4; 3 originating on anterior and one on posterior ceratohyal.

Muscular hiatus of pseudotympanum reduced, constricted by dorsal and ventral fibers of obliquus superioris muscle (Fig. 5f). Cavity anterior to first pleural rib, this as well as obliquus inferioris muscle not visible. Second pleural rib partially exposed.

Color in alcohol. Body pale yellow slightly darker dorsally due to presence of dark chromatophores along free edge of scales, lighter ventrally. Dorsal part of head and snout more densely pigmented with dark chromatophores. Lateral head and opercular bones with scattered dark chromatophores. Anterior upper edge of lower jaw also heavily pigmented with dark chromatophores. Dark lateral body stripe extending from
Table 13. Morphometrics of Acestrocephalus acutus. Standard length is expressed in mm; measurements through head length are percentages of standard length; last four entries are percentages of head length. Specimens are from MZUSP 31650 (holotype), 82105, 40830, 40691 (paratypes), MNRJ 17612, $18315,28716,28717,21136$ (paratypes), MCP15855 (paratype).

\begin{tabular}{lccccc}
\hline \multicolumn{1}{c}{ Characters } & Holotype & $\mathrm{N}$ & Range & Mean & SD \\
\hline Standard length & 80.0 & 47 & $50.0-103.5$ & & \\
Body depth & 26.6 & 41 & $23.5-28.6$ & 25.3 & 1.1 \\
Snout to dorsal-fin origin & 48.7 & 47 & $48.7-54.2$ & 51.4 & 1.0 \\
Snout to pectoral-fin origin & 30.7 & 47 & $27.6-31.5$ & 29.7 & 0.9 \\
Snout to pelvic-fin origin & 43.2 & 47 & $41.0-45.4$ & 42.5 & 1.1 \\
Snout to anal-fin origin & 59.0 & 47 & $56.1-61.4$ & 58.0 & 1.3 \\
Caudal peduncle depth & 8.1 & 47 & $7.5-8.8$ & 8.1 & 0.3 \\
Caudal peduncle length & 8.7 & 47 & $8.1-11.0$ & 9.4 & 0.5 \\
Pectoral-fin length & 17.7 & 47 & $14.7-18.3$ & 16.4 & 0.7 \\
Pelvic-fin length & 15.0 & 47 & $12.6-15.5$ & 13.7 & 0.8 \\
Dorsal-fin base length & 11.2 & 47 & $11.0-12.8$ & 11.7 & 0.4 \\
Dorsal-fin height & 25.3 & 47 & $21.2-26.6$ & 24.2 & 1.1 \\
Anal-fin base length & 35.6 & 47 & $32.7-37.6$ & 35.4 & 1.0 \\
Anal-fin height & 17.5 & 47 & $14.0-18.6$ & 15.7 & 1.3 \\
Eye to dorsal-fin origin & 34.1 & 47 & $34.1-37.8$ & 36.2 & 1.0 \\
Dorsal-fin origin to caudal-fin base & 51.5 & 47 & $48.6-53.2$ & 51.0 & 1.0 \\
Head length & 29.7 & 47 & $29.0-33.3$ & 30.4 & 0.8 \\
Horizontal eye diameter & 31.1 & 47 & $28.0-31.7$ & 29.4 & 0.8 \\
Snout length & 30.2 & 47 & $27.1-30.4$ & 28.6 & 0.7 \\
Least interorbital distance & 18.0 & 47 & $16.0-19.7$ & 17.6 & 0.7 \\
\hline
\end{tabular}

behind upper opercle to caudal peduncle, wider from below dorsal-fin origin to origin of adipose fin, narrower from below dorsal-fin origin anteriorly and on caudal peduncle. Oblong dark blotch on anterior caudal base joining dark lateral stripe, extending posteriorly to bases of middle caudal-fin rays. Mental area of lower jaw with conspicuous dark blotch in some specimens. Black spot at origin of dorsal fin very conspicuous, anteriorly extending over two or three predorsal scales, laterally over three or four scales of first horizontal scale row. All fins pale, first unbranched dorsal and pectoral fin rays with scattered dark chromatophores.

Distribution. Acestrocephalus acutus is known from the rio Tocantins and rio Tapajós drainages. It is sympatric with $A$. maculosus and A. stigmatus in the upper rio Tocantins (Fig. 8).

Remarks. The specimens from rio Teles Pires in the rio Tapajós drainage, not included as type material, are morphologically undistiguinshable from the holotype and paratypes, but examination of more specimens is required for better comparison.

Etymology. The species name acutus, adjective, from Latin meaning sharp is in reference to the pointed nature of the snout of this species.

\section{Acestrocephalus pallidus, new species}

Fig. 14

Holotype. MZUSP 35624, immature female, $60.5 \mathrm{~mm} \mathrm{SL}$, Brazil, Amazonas: rio Madeira, ilha do Puruzinho, by Expedição Permanente da Amazônia, 15 December 1975. 


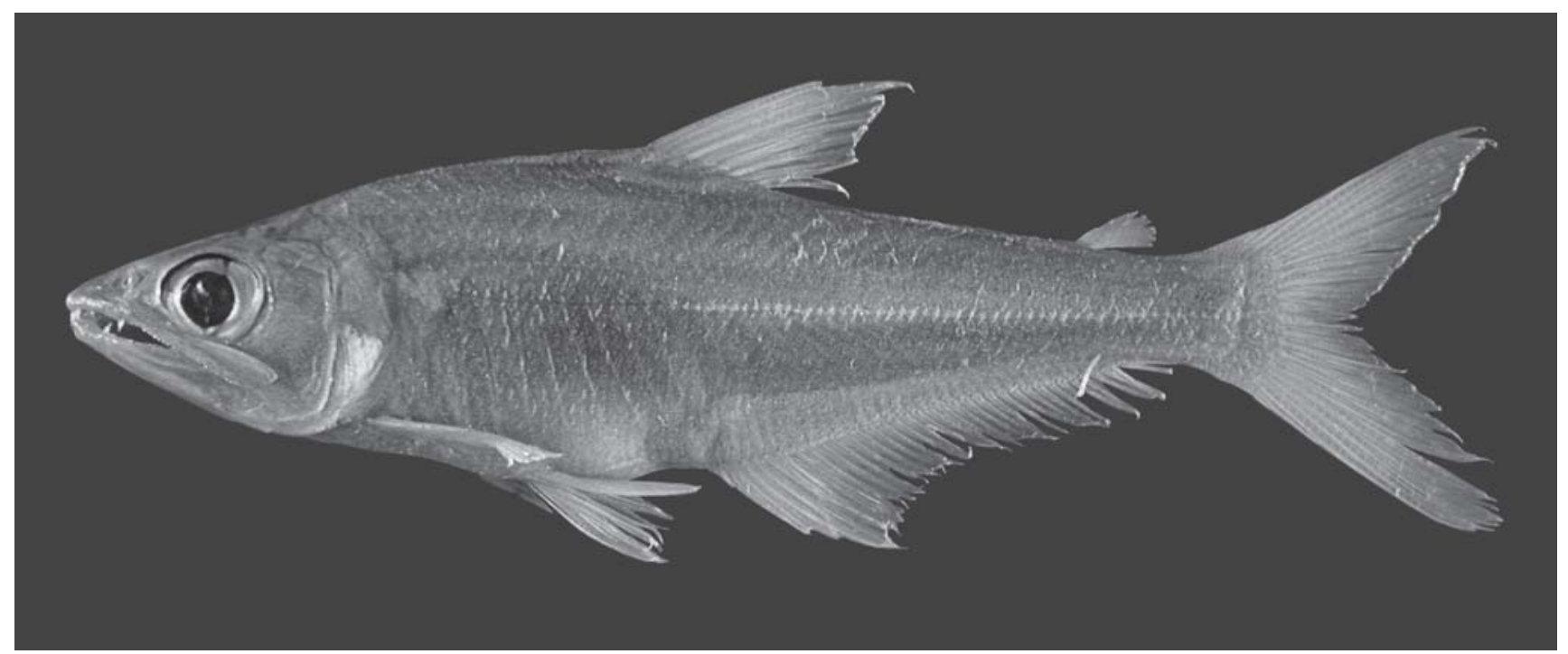

Fig. 14. Acestrocephalus pallidus, MZUSP 35624, immature female, 60.5 mm SL, ilha do Puruzinho, rio Madeira.

Paratypes. MZUSP 89586, 3, 52-60 mm SL, taken with holotype. MZUSP 76623, 2, 50 and $54.5 \mathrm{~mm}$ SL, Rondônia: rio Machado, Cururu, by Michael Goulding, 2 September 1980; MZUSP 63311, 10, 48.4-62 mm SL, 73471, 30, 40-66 mm SL, 73487, 1, $42.7 \mathrm{~mm}$ SL, 76627, 3, 41-46 mm SL, rio Machado, Paracaúba, by Michael Goulding, 4 September 1980.

Diagnosis. Acestrocephalus pallidus is distinguished from A. boehlkei, A. maculosus and A. stigmatus by lacking the dark humeral blotch characteristic of these species. Acestrocephalus pallidus has the eye smaller than $A$. sardina and $A$. nigrifasciatus (Fig. 4) and fewer maxillary teeth (30-38 vs 40-46. See Fig. 6). It differs from $A$. acutus by having only scattered dark chromatophores instead of the typical oblong dark blotch on the caudal-fin base of that species and the first pleural rib, the cavity anterior to it and the obliquus inferioris muscle visible $v s$ entirely covered by the fibers of the obliquus superioris muscle in A. acutus (compare Figs. $5 f$ and $5 \mathrm{~g})$.

Description. Morphometrics of holotype and additional specimens presented in Table 14. Meristic and morphometric data based on all examined lots because no statistical differences found among population samples studied. Body relatively small ( $\mathrm{SL}=40-66 \mathrm{~mm})$. Body form, dorsal and ventral body profiles, shape of snout and mouth and extension of maxilla as in A. sardina.

Dorsal-fin rays ii, 9 in all specimens, $n=60$, including holotype. Posterior most ray unbranched, $n=60$. Adipose fin present. Anal-fin rays iv,33 (iv or v, usually iv unbranched, branched rays mean $=33.5$, range $32-36, n=60$, posterior ray split to its base and counted as 1).Moderately developed anterior anal-fin lobe including anterior unbranched rays and first 10-11branched rays. No hooks on anal-fin rays, but sexual mature males not represented in the samples. Pectoral-fin rays $\mathrm{i}, 13$ (anterior unbranched ray $\mathrm{i}, \mathrm{n}=60$ branched rays mean $=13$, range $11-15, n=60)$. Posterior tips of longest pectoral-fin rays reaching slightly beyond origin of pelvic fin. Pelvic fin i, 7 , $n=60$. No hooks on pelvic-fin rays. Distal tips of longest pelvic-fin rays reaching anal-fin origin. Principal caudal-fin ray count $10 / 9, n=60$.

Lateral line complete, perforated scales 72 (mean $=71.6$, range $68-74, \mathrm{n}=60)$. Scale rows above lateral line 13 (mean=12.2, range $12-13, \mathrm{n}=60)$. Scale rows below lateral line 11 (mean=11, range $10-11, \mathrm{n}=60)$. Scale rows around caudal peduncle 22 (mean=21.5, range $21-23, \mathrm{n}=60$ ).

Shape, size and arrangement of teeth on premaxilla, maxilla and dentary as in $A$. sardina. Outer row small conical

Table 14. Morphometrics of Acestrocephalus pallidus. Standard length is expressed in mm; measurements through head length are percentages of standard length; last four entries are percentages of head length. Specimens are from: MZUSP 35624 (holotype), 89586, 76236, 73471, 73487, 76627, and 63311 (paratypes).

\begin{tabular}{lccccc}
\hline \multicolumn{1}{c}{ Characters } & Holotype & $\mathrm{N}$ & Range & Mean & SD \\
\hline Standard length & 60.5 & 60 & $40.0-66.0$ & & \\
Body depth & 28.1 & 50 & $24.1-28.4$ & 26.1 & 1.0 \\
Snout to dorsal-fin origin & 51.7 & 60 & $48.7-53.3$ & 50.7 & 0.8 \\
Snout to pectoral-fin origin & 28.1 & 60 & $26.2-29.7$ & 28.0 & 0.6 \\
Snout to pelvic-fin origin & 42.1 & 60 & $39.1-43.1$ & 41.0 & 0.8 \\
Snout to anal-fin origin & 55.5 & 60 & $53.2-57.4$ & 55.3 & 0.9 \\
Caudal peduncle depth & 8.6 & 60 & $7.5-8.7$ & 8.1 & 0.2 \\
Caudal peduncle length & 9.6 & 60 & $9.1-11.0$ & 9.8 & 0.5 \\
Pectoral-fin length & 17.7 & 60 & $16.0-18.3$ & 17.2 & 0.5 \\
Pelvic-fin length & 15.3 & 60 & $14.1-16.2$ & 15.1 & 0.4 \\
Dorsal-fin base length & 11.9 & 60 & $10.3-12.5$ & 11.6 & 0.4 \\
Dorsal-fin height & 24.8 & 60 & $23.2-26.5$ & 24.8 & 0.8 \\
Anal-fin base length & 38.0 & 60 & $35.8-40.0$ & 37.7 & 1.1 \\
Anal-fin lobe length & 18.1 & 60 & $16.2-18.8$ & 17.7 & 0.7 \\
Eye to dorsal-fin origin & 35.5 & 60 & $33.0-36.0$ & 34.8 & 0.6 \\
Dorsal-fin origin to caudal-fin base & 53.0 & 60 & $50.0-53.6$ & 52.1 & 0.8 \\
Head length & 30.5 & 60 & $28.8-31.2$ & 30.0 & 0.5 \\
Horizontal eye diameter & 32.4 & 60 & $29.0-34.1$ & 32.2 & 1.0 \\
Snout length & 29.7 & 60 & $26.7-30.0$ & 28.1 & 0.8 \\
Least interorbital width & 19.0 & 60 & $17.6-22.0$ & 19.6 & 1.0 \\
Upper jaw length & 64.8 & 60 & $60.3-65.6$ & 63.4 & 1.1 \\
\hline
\end{tabular}


teeth on premaxilla 9 (mean $=7.8$, range $7-10, n=60)$. Maxillary teeth 31 (mean=33.8, range 30-38, $\mathrm{n}=60$ ), tending to increase in number with an increase in standard length (Fig.6). Posterior row dentary teeth 34 (mean=32.2, range 29-37, $n=60$ ), also tending to increase in number with an increase in standard length (Fig. 7). Inner row dentary teeth 9 (mean=10.8, range 9$13, \mathrm{n}=60$ ).

Vertebrae 38 (mean $=38.7$, range $38-39, n=47)$. Total number of gill-rakers on first gill-arch 7 (mean=6.4, range 6-7, $n=60$ ).

Shape of muscular hiatus of pseudotympanum, arrangement of associated muscles and remaining structures (Fig. $5 \mathrm{~g}$ ) as in A. sardina.

Color in alcohol. Body pale yellow with no distinct dark spots or blotches. Scatered dark chromatophores present on dorsal head and snout and along free edge of scales on dorsal trunk being slightly darker than remaining parts of body. Dark chromatophores on caudal-fin base scattered, visible only using stereomicroscope, not forming a blotch. Dark spot at dorsalfin origin weak and dark color on lower jaw mental area sometimes diffuse. Lateral body stripe largely consisting of guanine pigment extending from posterior section dorsal opercle to caudal-fin base. All fins pale.

Distribution. Known only from rio Madeira and rio Machado, a tributary of rio Madeira (Fig. 8).

Etymology. The species name pallidus, adjective, from the Latin for pale is in reference to the overall body color of this species.

\section{Acknowledgments}

For providing radiographs and digital images of type specimens I am grateful to David Catania (California Academy of Sciences, San Francisco, USA), Mark Sabaj (The Academy of Natural Sciences of Philadelphia), and Karsten Hartel and Andrew Williston (Museum of Comparative Zoology, Harvard University, USA). Heraldo A. Britski (MZUSP) examined, took data and photographed the holotype of Acestrocephalus sardina. The photographs of fishes, drawings and radiographs of fish structures in this paper were prepared by Eduardo Gouveia Baena (MZUSP).

Assistance in the use of statistical computer programs was provided by Alberto Akama and José Luís O. Birindelli (MZUSP). Flávio C.T. Lima (MZUSP) and Mônica Toledo PizaRagazzo (Departamento de Zoologia, Instituto de Biociências, Universidade de São Paulo) helped in many ways, read the manuscript and made useful comments. This paper also benefited from review by M.W. Littman (Field Museum of Natural History, Chicago, USA). Osvaldo T. Oyakawa (MZUSP), Paulo A. Buckup (MNRJ) and Carlos A.S. de Lucena and Zilda Margarete de Lucena (MCP) arranged for the loan of specimens and provided useful information. The distribution map is based on a map of South America prepared by Marilyn Weitzman.
Collecting permits were issued by Instituto Brasileiro do Meio Ambiente e dos Recursos Naturais Renováveis IBAMA (processo IBAMA 02027.007616/99-98). Some specimens used in this study were obtained using financial support from Conselho Nacional de Desenvolvimento Científico e Tecnológico - CNPq, through PRONEX Project 661058/19972 to the author.

\section{Literature Cited}

Böhlke, J. E. 1984. Catalog of the type specimens in the ichthyological collection of the Academy of Natural Sciences of Philadelphia. Special Publication, 14: 1-246.

Eschmeyer, W. N. (ed). 1998. Catalog of Fishes. California Academy of Sciences, San Francisco, 2905 p.

Fink, W. L. \& S. H. Weitzman. 1974. The so called cheirodontin fishes of Central America with descriptions of two new species (Pisces: Characidae). Smithsonian Contributions to Zoology, 172: 1-46.

Fowler, H. W. 1913. Fishes of the Madeira River, Brazil. Proceedings of the Academy of Natural Sciences of Philadelphia, 65(3): 517579.

Fowler, H. W. 1950. Os peixes de água doce do Brasil (2 entrega). Arquivos de Zoologia, São Paulo, 6: 205-404.

Géry, J. 1972. Corrected and supplemented descriptions of certain characoid fishes described by Henry W. Fowler, with revisions of several of their genera. Studies on Neotropical Fauna and Environments, 7: 1-35.

Lasso, C. A. \& D. Taphorn. 2000. A new species of Acestrocephalus (Characiformes: Characidae) from Venezuela. Revista de Biologia Tropical, 48(2): 443-447.

Lasso, C. A., D. Lew, D. Taphorn, C. Nascimiento, O. Lasso-Alcalá, F. Provenzano \& A. Machado-Allison. 2004. Biodiversidade ictiológica continental de Venezuela. Parte 1. Lista de espécies y distribución por cuencas. Memória Fundación La Salle de Ciências Naturales, 159-160 (for 2003): 105-195.

Lima, F. C. T., L. Ramos, T. Barreto, A. Cabalzar, G. Tenório, A. Barbosa, F. Tenório, A. S. Resende \& M. Lopes. 2005. Peixes do Alto Tiquié. Ictiologia e conhecimentos dos Tuyuka e Tukano. Pp. 111-304. In: A. Cabalzar, (org.). Peixe e gente no alto rio Tiquié. São Paulo: Instituto Ambiental, 339 p.

Lucena C. A. S. \& N. A. Menezes. 2003. Subfamily Characinae. Pp. 200-208. In: R.E. Reis, S.O. Kullander \& C.J. Ferraris (eds). Check list of freshwater fishes of South and Central America. Edipucrs, Porto Alegre, 729 p.

Menezes, N. A. 1976. On the Cynopotaminae, a new subfamily of the Characidae (Osteichthyes, Ostariophysi, Characoidei). Arquivos de Zoologia, São Paulo, 28(10): 1-91.

Menezes, N. A. 1977. Acestrocephalus boehlkei, a new and disjunct Cynopotamine from Ecuadorean and Peruvian Amazon (Osteichthyes, Ostariophysi, Characidae). Papéis Avulsos de Zoologia, São Paulo, 30(3): 185-193.

Submitted July 2006 Accepted November 2006 